UNIVERSIDADE DE BRASÍLIA - UnB

FACULDADE DE DIREITO

JULIANA DA ROCHA MATOS

A SÚMULA IMPEDITIVA DE RECURSO À LUZ DO PRINCÍPIO DO ACESSO À JUSTIÇA E A INVIOLABILIDADE DO DUPLO GRAU DE JURISDIÇÃO 
JULIANA DA ROCHA MATOS

\title{
A SÚMULA IMPEDITIVA DE RECURSO À LUZ DO PRINCÍPIO DO ACESSO À JUSTIÇA E A INVIOLABILIDADE DO DUPLO GRAU DE JURISDIÇÃO
}

\author{
Monografia apresentada à Faculdade de Direito \\ da Universidade de Brasília (UnB), como \\ requisito à obtenção do título de Bacharel em \\ Direito.
}

Orientador: Prof. Henrique Araújo Costa 


\section{A SÚMULA IMPEDITIVA DE RECURSO À LUZ DO PRINCÍPIO DO ACESSO À JUSTIÇA E A INVIOLABILIDADE DO DUPLO GRAU DE JURISDIÇÃO}

Monografia apresentada à Faculdade de Direito da Universidade de Brasília (UnB), como requisito à obtenção do título de Bacharel em Direito.

Banca Examinadora:

Orientador: Henrique Araújo Costa

Membro: Doutor Vallisney de Souza Oliveira

Membro: Doutorando André Macedo de Oliveira 
Aos meus pais e irmão, queridos companheiros de toda a vida, com enorme gratidão. 
A necessidade de procurar a verdadeira felicidade é o fundamento da nossa liberdade.

John Locke 


\section{RESUMO}

Este estudo tem como objetivo examinar se a súmula impeditiva de recursos, prevista no artigo 518, parágrafo primeiro, do Código de Processo Civil de 1973, viola o princípio do duplo grau de jurisdição e, consequentemente, o acesso à justiça daquele que busca a tutela jurisdicional, uma vez que permite ao juiz obstar o prosseguimento do recurso, com fundamento em súmula do STJ ou do STF, limitando ao recorrente o direito ao recurso de apelação. Embora se limite a aferir a possibilidade, ou não, de ofensa ao já consagrado princípio do duplo grau de jurisdição, este trabalho destaca o questionamento sobre a supressão de uma etapa, relevante no processo civil, no caso a recursal. Para tanto, estudam-se os contornos interpretativos sobre o princípio do duplo grau de jurisdição e do acesso à justiça, para depois passar à análise dos reflexos dessa interpretação no exame do referido mecanismo processual. Partindo-se da demonstração de que o princípio do duplo grau de jurisdição existe apenas como um princípio, presente de forma implícita na Constituição, mas não como uma garantia constitucional, passa-se, em um segundo momento, para a apreciação dos caminhos percorridos para se chegar à concepção contemporânea do princípio do acesso à justiça. Além disso, mostra-se que os reflexos desse conceito ocorreram na Constituição Federal com a adoção de alguns princípios, como o da celeridade e o da duração razoável do processo. Logo em seguida, o estudo busca examinar as relações da súmula impeditiva de recursos em face do ordenamento jurídico, a partir da análise da natureza do instituto e de seus efeitos, para finalmente concluir que a adoção da súmula impeditiva de recursos não violou o princípio constitucional do duplo grau de jurisdição. Nessa parte, destaca-se, também, o aspecto do fomento de preceitos da Constituição, como o da celeridade processual, em contraposição à redução de alguns outros, como do próprio duplo grau de jurisdição. Como último aspecto, o estudo volta-se para considerações sobre a abolição da súmula impeditiva de recursos no novo Código de Processo Civil e para a conclusão de que, apesar dessa abolição, a técnica de vinculação a precedentes, empregada pelo instituto, é aplicada com grande ênfase no novo diploma processual.

Palavras-chave: Código de Processo Civil. Recursos. Súmula Impeditiva. Princípios.

Duplo grau de jurisdição. Acesso à justiça. 


\section{SUMÁRIO}

INTRODUÇÃ

I. O PRINCÍPIO DO DUPLO GRAU DE JURISDIÇÃO ........................................ 10

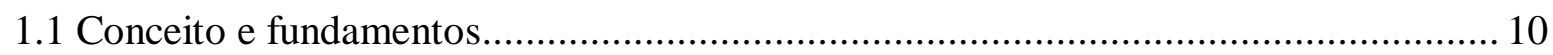

1.2 O princípio do duplo grau na Constituição Brasileira ................................................. 12

1.2.1 O duplo grau de jurisdição na Constituição Federal: garantia ou apenas princípio

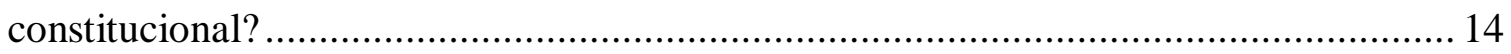

II. O PRINCÍPIO DO ACESSO À JUSTIÇA ................................................................ 19

2.2 Noções introdutórias sobre o acesso à justiça ............................................................ 19

2.2 Visão contemporânea do princípio do acesso à justiça ............................................. 22

$2.3 \mathrm{O}$ princípio da celeridade e da duração razoável do processo e do acesso à justiça ...... 24

III. A SÚMULA IMPEDITIVA DE RECURSOS ..................................................... 28

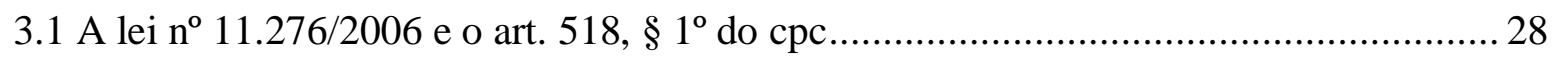

3.2 Juízo de admissibilidade ou mérito recursal?.........................................................2 29

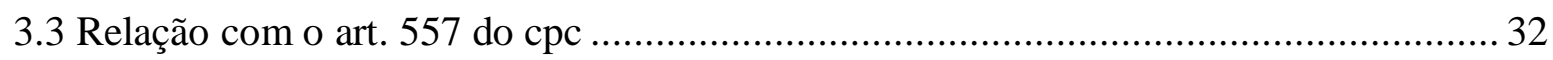

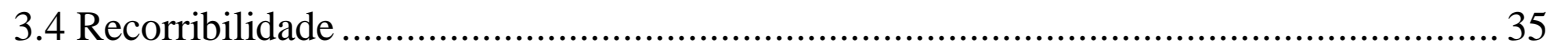

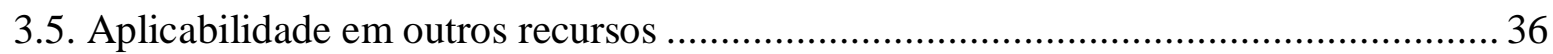

IV. SÚMULA IMPEDITIVA DE RECURSOS: A QUESTÃO DO DUPLO GRAU DE

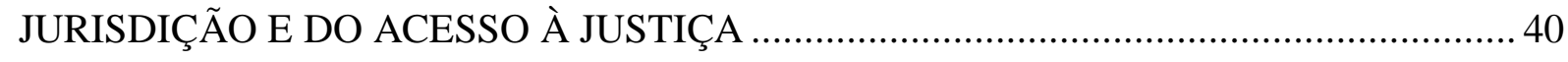

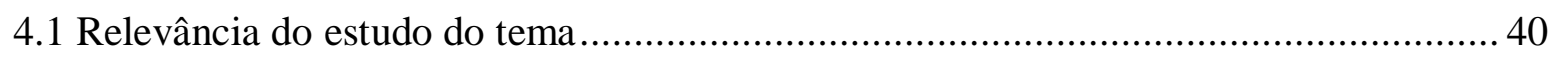

4.2 A súmula impeditiva de recursos e o princípio do duplo grau de jurisdição ................. 40

V. CONSIDERAÇÕES SOBRE A SÚMULA IMPEDITIVA DE RECURSOS E O NOVO

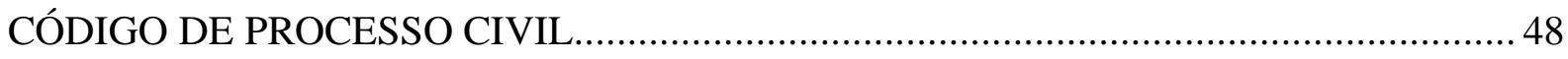

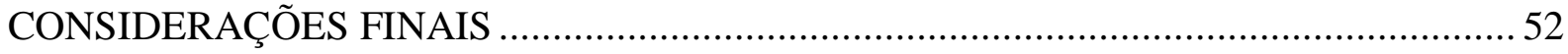

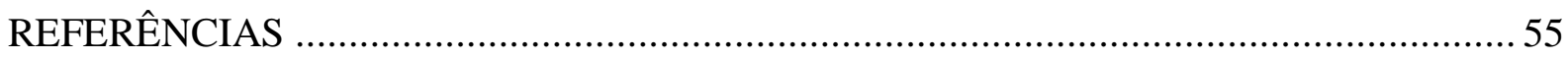




\section{INTRODUÇÃO}

O presente estudo tem como objetivo uma análise sobre o artigo 518, parágrafo $1^{\circ}$, do vigente Código de Processo Civil de 1973. Esse dispositivo é conhecido, na linguagem processual, com a denominação de súmula impeditiva de recursos.

Inserida pela Lei $\mathrm{n}^{\mathrm{o}} 11.276$, de 2006, a súmula impeditiva de recursos possibilita ao magistrado de primeiro grau impedir o prosseguimento do recurso de apelação quando a sentença estiver em conformidade com súmula do Superior Tribunal de Justiça ou do Supremo Tribunal Federal. O dispositivo foi criado, na linha de outras alterações no sistema processual, mas em especial como consequência da Emenda Constitucional no 45 de 2004, que objetivaram imprimir maior celeridade e efetividade à tramitação processual.

Na iminência da implementação do novo Código de Processo Civil, torna-se relevante a discussão em torno dos mecanismos de seletividade judicial, inseridos pelo ainda vigente diploma processual de 73, como o da súmula impeditiva, que utilizam como técnica a vinculação a precedentes, uma vez que o emprego dessa técnica passa a ser uma das características mais marcantes desse novo Código.

Embora em certo ponto coerente com o caminho que vem sendo tomado pelo legislador, no tocante ao objetivo de racionalizar e conferir celeridade à prestação jurisdicional, esses mecanismos processuais suscitam dúvidas e questionamentos, diante da necessidade de leitura dos novos e dos tradicionais institutos processuais sob enfoque do modelo constitucional do processo.

Dentre os vários questionamentos, aqueles que se opõem à aplicação da súmula impeditiva de recursos alegam que, não obstante a tentativa de celeridade, com a duração razoável do processo, o instituto relega a um segundo plano o direito ao duplo grau de jurisdição, restringindo o direito da parte vencida de recorrer, o que, consequentemente, viola o princípio do acesso à justiça, previsto no artigo $5^{\circ}$, inciso XXXV, da Constituição Federal.

Tendo em vista essa restrição ao recurso de apelação, objetiva-se analisar, no presente trabalho, se a súmula impeditiva de recursos viola, efetivamente, o princípio recursal do duplo grau de jurisdição e, consequentemente, o acesso daquele que busca a tutela jurisdicional. Esse questionamento esbarra na tendência de verificação da eficiência da prestação jurisdicional, que compreende o direito à tempestividade da tutela, onde ensejaria uma preferência sobre o princípio do duplo grau de jurisdição. Torna-se necessário, também, 
o esclarecimento sobre se o duplo grau de jurisdição é considerado, realmente, um princípio, ou mesmo uma garantia constitucional.

Para essa finalidade, estruturou-se o presente trabalho em cinco capítulos.

O Capítulo I analisará o conceito e os fundamentos estabelecidos sobre o duplo grau de jurisdição. Logo em seguida, será esclarecido se o duplo grau é um princípio constitucional e, em caso afirmativo, qual a sua natureza, se de mero princípio ou garantia constitucional do processo.

O Capitulo II abordará as concepções adotadas sobre o princípio do acesso à justiça ao longo do tempo e sua atual percepção, relacionando os princípios da celeridade e da duração razoável do processo, adotados pela Constituição Federal, como reflexo dessa atual concepção.

O Capítulo III tem por objetivo mostrar de que forma a súmula impeditiva atua no sistema processual. Dessa forma, o capítulo será dedicado ao estudo das especificidades em torno da aplicação do instituto: sua criação pela Lei $\mathrm{n}^{\mathrm{o}} 11.276 / 2006$ e os seus desdobramentos no sistema processual; sua natureza, se de juízo de admissibilidade ou de mérito recursal; a relação que comumente se estabelece entre a súmula impeditiva e o art. 557 do Código de Processo Civil; a recorribilidade; e a aplicabilidade do instituto em outros tipos de recurso, que não o de apelação.

Já o capítulo IV analisará o principal objetivo deste trabalho, ou seja, investigar se a súmula impeditiva viola o princípio do duplo grau de jurisdição, a partir dos contornos interpretativos sobre o duplo grau e o princípio do acesso à justiça e sobre a natureza jurídica do instituto estabelecidos nos capítulos anteriores.

Finalmente, o Capítulo V fará algumas considerações sobre alguns dos objetivos pretendidos pela reforma processual realizada no atual Código de Processo Civil, no que diz respeito à adoção de mecanismo de seletividade judicial, tendo como exemplo a própria súmula impeditiva de recursos e os reflexos dessa adoção sobre o novo CPC. 


\section{O PRINCÍPIO DO DUPLO GRAU DE JURISDIÇÃO}

\subsection{CONCEITO E FUNDAMENTOS}

O princípio do duplo grau de jurisdição consiste em possibilitar que toda decisão judicial, por meio da interposição de recurso, seja submetida a nova revisão, normalmente por órgão de jurisdição diverso e de hierarquia superior à daquele que proferiu a primeira decisão (NERY JUNIOR, 2004, p. 44).

Esse princípio permite que se devolva ao órgão superior toda a causa já decidida pelo juiz e todas as questões relevantes para seu julgamento - tais como, "questões de fato ou de direito, referentes ao mérito ou ao processo, matéria constitucional ou infraconstitucional, direito federal ou não etc.” (DINAMARCO, 2009, p. 243). ${ }^{1}$ É a partir do referido princípio que as lides ajuizadas submetem-se a exames sucessivos, como "garantia de boa solução" (MOREIRA, 2008, v. 5, p. 237).

Um dos principais argumentos para justificar o duplo grau de jurisdição é da possibilidade de falha do ser humano. Não seria razoável o juiz ser considerado homem imune a falhas, capaz de decidir de modo definitivo, sem que ninguém pudesse questionar sua fundamentação ao julgar (NERY, 2004, p. 39). Além dessa circunstância, há também razões de natureza social e político-institucional, apesar de ainda existir na doutrina entendimento, hoje minoritário, que se manifesta contrariamente à sua aplicação (CINTRA; GRINOVER; DINAMARCO, 2009, p. 80).

Na perspectiva social, o princípio do duplo grau de jurisdição tem como fundamento a possibilidade de dar à parte sucumbente o direito ao reexame da decisão com a qual não se conformou. Isso porque nosso subjetivismo nos coloca naturalmente contra decisão desfavorável, impelindo-se a pretender, pelo menos, novo julgamento sobre a questão (NERY JUNIOR, 2004, p. 39). É a conveniência psicológica de oferecer ao sucumbente mais uma oportunidade de êxito. Além disso, como observa Dinamarco, circunscrever os julgamentos em um único grau de jurisdição possibilita conter litigiosidades e permitir que se perpetue estados de insatisfação e desconfiança, que poderão ser acrescidos por revoltas e possíveis agravamentos da situação (DINAMARCO, 2009, p. 243).

\footnotetext{
${ }^{1}$ De forma diversa, Marinoni, por exemplo, entende que a noção de duplo grau de jurisdição impõe que qualquer decisão judicial, da qual possa resultar algum prejuízo jurídico, admita revisão judicial por órgão judiciário diferente daquele que proferiu a primeira decisão, não necessariamente de maior hierarquia, um inferior e outro superior, sendo que, nessa linha de pensamento, o duplo grau de jurisdição poderia ser melhor definido como um duplo juízo sobre o mérito (MARINONI; ARENHART, 2008, p. 496).
} 
Já na perspectiva político-institucional, o princípio do duplo grau de jurisdição tem como base dois importantes fundamentos. O primeiro diz respeito à conveniência de evitar a dispersão de julgados e com isso promover a relativa uniformização da jurisprudência com relação à interpretação da Constituição e da lei federal. O segundo faz referência à necessidade de pôr os juízes de hierarquia inferior sob o controle dos de hierarquia superior, como forma de evitar abusos de poder daqueles nos processos em que atuam e legitimar a atuação do Poder Judiciário como um todo (DINAMARCO, 2009, p. 243).

Esse último argumento tem, claramente, como base a ideia de Estado de Direito que exige o controle das atividades dos poderes estatais pela sociedade. Assim, afirma Wambier (2002, p. 140), o duplo grau desempenha função de controle, tanto no plano da sociedade que, representada pelas partes, exerce o controle da atividade estatal por meio do manejo de recursos, quanto no plano interno do Poder Judiciário, haja vista que os órgãos hierarquicamente superiores "controlam", de certo modo, as decisões dos inferiores. ${ }^{2}$ Entretanto, entendo que esse argumento reduz a finalidade principal do duplo grau que é o controle da justiça da decisão. Esse controle, para o direito moderno, não pode ser confundido com o controle da própria atividade do juiz. Como observa Marinoni (2008, p. 496), "não há que se falar em controle da atividade do juiz quando se está discutindo sobre a oportunidade de dar ao vencido o direito à revisão da decisão que lhe foi contrária."

Segundo Barbosa Moreira (2008), invoca-se a possibilidade do ordenamento jurídico prever o duplo grau de jurisdição, pois parece razoável entender que há maior probabilidade de acerto dos pronunciamentos judiciais em decorrência da sua sujeição ao crivo do reexame. Ele acrescenta, ainda, que o julgamento do recurso, em regra, é realizado por juízes mais experientes, em órgãos colegiados, diminuindo a possibilidade de ficarem despercebidos aspectos relevantes para correta apreciação da causa. Como ressalta o referido autor,

É dado da experiência comum que uma segunda reflexão acerca de qualquer problema freqüentemente conduz a mais exata conclusão, já pela luz que projeta sobre ângulos até então ignorado, já pela oportunidade que abre para reavaliação de argumentos a que no primeiro momento talvez não se tenha atribuído o justo peso. (MOREIRA, 2008, v. 5, p. 237).

$\mathrm{Na}$ realidade, a meu ver, todas essas razões que buscam justificar a aplicação do princípio do duplo grau de jurisdição, quando analisadas em conjunto,

\footnotetext{
2 Como observa Wambier (2002, p. 140), “anote-se aqui que não se trata propriamente de hierarquia, já que os órgãos superiores não exercem 'autoridade' sobre inferiores.” A censura, em questão, é feita pelo destinatário do recurso, estritamente, no plano jurisdicional, sem interferir na independência do juiz a quo (DINAMARCO, 2009, p. 245).
} 
constituem elementos para configuração do desejável equilíbrio entre a segurança jurídica e a ponderação dos julgamentos, sendo este último elemento responsável pela melhor qualidade e maior confiabilidade das decisões.

E assim, a partir desses fundamentos, o princípio é recepcionado pela generalidade dos sistemas processuais contemporâneos, inclusive o brasileiro, apesar de haver, no caso brasileiro, em sede de doutrina, controvérsias quanto à adoção do referido princípio pela Constituição (CINTRA; GRINOVER, DINAMARCO, 2009).

\subsection{O PRINCÍPIO DO DUPLO GRAU NA CONSTITUIÇÃO BRASILEIRA}

No Brasil, a previsão do princípio do duplo grau de jurisdição, de maneira expressa, remete-se à Constituição do Império de 1824. A Carta Imperial foi a única constituição brasileira que previu o princípio, ilimitadamente, de modo claro e irrestrito, no seu artigo $158^{3}$. Daí para frente, todas as constituições seguintes limitaram-se a apenas mencionar a existência de tribunais, outorgando-lhes competência recursal, não considerando expressamente a existência do princípio (NERY JUNIOR, 2009, p. 280).

Atualmente, sob o regime da Constituição de 1988, entende-se, de forma majoritária, que o princípio do duplo grau de jurisdição, embora não se encontre expressamente indicado, esteja previsto implicitamente dentro do texto constitucional. Ao contrário, há uma parcela muito reduzida da doutrina que entende pela sua não existência.

Roberto Rosas, por exemplo, alega a existência de dois argumentos para a inexistência do princípio do duplo grau na atual Constituição Federal. O primeiro diz respeito à falta de texto normativo expresso que faça referência ao princípio. Já o segundo argumento diz respeito ao fato de que, a partir da análise estrutural do sistema judicial imposto pela Constituição, em muitas oportunidades, não há obediência ao duplo grau de jurisdição, como ocorre nas causas de competência originária do Supremo Tribunal Federal ${ }^{4}$ (ROSAS, 1999, p. 21).

Entretanto, como referido acima, o entendimento majoritário é o que considera o duplo grau de jurisdição um princípio constitucional do processo, apesar de não estar, de fato, expresso na Constituição. Para isso, a doutrina elenca alguns argumentos.

\footnotetext{
3 Constituição do Império, de 25.3.1824:

“art. 158: Para julgar as Causas em segunda e última instância haverá nas Províncias do Império as Relações, que forem necessárias para commodidade dos Povos."

${ }^{4}$ Segundo Nelson Nery (2004, p. 48), "no que concerne à competência originária do STF (CF 102 I), aqui realmente não há previsão de recurso ordinário e regular a outro órgão, já que o STF é o tribunal máximo do país."
} 
O primeiro ponto de fundamentação diz respeito ao fato de que a ordem constitucional brasileira expressa clara opção pela possibilidade de interpor recursos contra as decisões judiciárias. Ela estabelece a competência dos tribunais de superposição para o julgamento do recurso ordinário, do extraordinário e do especial. Também, dispõe sobre os recursos a serem direcionados aos tribunais integrantes da justiça da União, como por exemplo, os recursos para o Tribunal Superior do Trabalho e Tribunais Regionais Federais. E, ainda, prevê, nas justiças estaduais, órgãos inferiores e superiores de jurisdição (DINAMARCO, 2009, p. 242). Portanto, ela descreve a estrutura do Poder Judiciário e cria Tribunais, cuja função, preponderante, é a de julgar recursos (WAMBIER, 2002, p. 140).

Já o segundo argumento, que conduz ao entendimento da previsão constitucional do princípio, é o da admissão do duplo grau de jurisdição como princípio imanente ao devido processo legal, que se encontra previsto no artigo $5^{\circ}$, LIV, da CF: "ninguém será privado da liberdade ou de seus bens sem o devido processo legal". A partir desse entendimento, observa-se que, para existência do devido processo legal, é necessário que os princípios componentes deste, entre eles o duplo grau de jurisdição, sejam garantidos. Há uma relação de dependência entre os referidos princípios, concluindo-se, assim, pela incidência do princípio do duplo grau, implicitamente, dentro do texto constitucional.

Por outro lado, entende-se, também, que apesar do duplo grau de jurisdição ser considerado um princípio constitucional, a própria Constituição Federal cria limites para esse princípio, não garantindo de forma absoluta o direito ao duplo grau. Dinamarco (2009) mostra que, além de não explicitar exigência alguma a respeito, a própria Constituição considera hipóteses em que a jurisdição será exercida em grau único, sem possibilidade de recurso. Dessa maneira, observa o autor,

Assim sucede com os casos de competência originária dos tribunais da Justiça
comum (Regionais Federais ou de Justiça), cujos acórdãos só poderão ser objeto de
recurso extraordinário ou especial quando concretamente concorrerem os
rigorosíssimos pressupostos a que estes estão condicionados. Mais excepcional
ainda é a recorribilidade dos acórdãos do próprio Supremo Tribunal Federal e do
Superior Tribunal de Justiça [...]." (DINAMARCO, 2009, p. 246).

Dessa forma, há o entendimento de que o princípio do duplo grau de jurisdição, muito embora esteja previsto na Constituição, não tem incidência ilimitada. Isso porque, afirma Nelson Nery Junior (2009), o binômio segurança-justiça não se efetiva quando os litígios perpetuam-se no tempo, a pretexto de conferir maior segurança àqueles que estão em juízo em busca da prestação jurisdicional. Nesses termos, destaca o autor:

O objetivo do duplo grau de jurisdição é, portanto, fazer adequação entre a realidade no contexto social de cada país e o direito à segurança e à justiça das decisões judiciais, que todos têm de acordo com a Constituição Federal. 
Essa é a razão porque a nossa Constituição não garante o duplo grau de jurisdição ilimitadamente [...].” (NERY JUNIOR, 2009, p. 40).

No entanto, é válido ressaltar que, apesar do entendimento posto acima, a possibilidade de se imprimir limites ao duplo grau de jurisdição gera divergência na doutrina. Essa divergência gira em torno da obrigatoriedade, ou não, de aplicação do princípio no ordenamento jurídico brasileiro. Parte da doutrina considera o princípio uma garantia constitucional, com exigência de ser efetivamente observado pela lei. Já outra parte entende o duplo grau de jurisdição como um princípio constitucional, mas não uma garantia, diferentemente do que ocorre com os demais princípios integrantes da denominada "tutela constitucional do processo" (DINAMARCO, 2009, p. 246).

Assim, tendo como ponto de partida a divergência acima, passe-se a análise dessa questão, no próximo tópico.

\subsubsection{O duplo grau de jurisdição na Constituição Federal: garantia ou apenas princípio constitucional?}

Identificar qual a natureza constitucional do princípio do duplo grau de jurisdição é de essencial importância para se compreender seus efeitos na ordem jurídica. Como foi visto, há uma divergência na doutrina quanto ao caráter de imperatividade do duplo grau de jurisdição no ordenamento jurídico brasileiro.

Cabe ressaltar que a doutrina processual civil construiu e equacionou a divisão dos princípios relativos ao direito processual civil em (i) princípios informativos; e (ii) princípios fundamentais. Os primeiros são considerados quase como axiomas, estritamente técnicos, e são classificados em: lógico, jurídico, político e econômico. Já os princípios fundamentais seguem a orientação do sistema jurídico a que estão vinculados, considerando aspectos políticos e ideológicos.

Interessante observar que essa noção de princípios fundamentais decorre da ideia de que os princípios jurídicos incorporam valores. Como pode haver colisão entre valores, de maneira correlata, pode ocorrer colisão entre princípios, que deve ser "resolvida" em face do caso concreto (WAMBIER, 2002, p. 140). Dessa forma, o que se percebe, em tese, "é que os princípios não comportam um tratamento rígido" (WAMBIER, 2009, p. 140), não se fazendo possível organizá-los de forma escalonada e hierarquizada, com caráter de imperatividade uns em relação aos outros. 
Portanto, apesar de os princípios fundamentais relativos ao direito processual - incluindo nessa categoria os princípios gerais relativos aos recursos, inclusive o princípio do duplo de jurisdição - serem regras gerais básicas que norteiam um determinado sistema jurídico, não incidem como se fosse uma minuciosa norma posta. Paradoxalmente, a incidência desses princípios, nesses moldes, poderia lhes retirar "o status, a grandeza e abrangência, própria dos princípios.” (WAMBIER, 2009, p. 137).

Por outro lado, apesar dessa noção adotada com relação aos princípios fundamentais do processo, a divergência com relação à obrigatoriedade do duplo grau ocorre na doutrina. Considerado um princípio recursal, o duplo grau de jurisdição está relacionado ao direito que o jurisdicionado tem de poder submeter a novo exame decisão judicial que lhe foi adversa. Assim, segundo aqueles que entendem o duplo grau como garantia constitucional, esse direito é um imperativo de ordem jurídico-constitucional, decorrente do princípio do devido processo legal, não podendo a lei ordinária limitá-lo. Nesses temos, esclarece Djanira Maria Radamés de Sá:

[...] constitui o direito à impugnação da sentença de mérito um imperativo de ordem jurídico-constitucional revestido do status de garantia constitucional e sendo negado ao jurisdicionado o acesso à atividade recursal patenteia-se o desrespeito [...] ao princípio do duplo grau de jurisdição. (SÁ, 2008, p. 69).

Todavia, tem-se demonstrado que o princípio do duplo grau de jurisdição não está garantido de forma absoluta no sistema constitucional brasileiro. Apesar de o duplo grau ser considerado um princípio constitucional, como já salientado anteriormente, a própria Constituição limita o seu âmbito de abrangência ao apresentar hipóteses em que é excepcional a recorribilidade dos julgados. Válido citar, por exemplo, os casos restritos em que cabe o recurso especial e o extraordinário, previstos na Constituição Federal; o fato de a Constituição dizer que as decisões do Tribunal Superior Eleitoral são irrecorríveis, salvo quando contrariem a Constituição Federal e as denegatórias de habeas corpus ou mandado de segurança ${ }^{5}$; entre outras hipóteses.

Ademais, o princípio do duplo grau de jurisdição deve ter aplicação moderada pelos ordenamentos jurídicos para que o processo civil não se dissocie da realidade contemporânea (NERY JUNIOR, 2009). Assim, sem perder de vista o valor segurança, buscase, também, uma justiça mais efetiva e rápida. Nesse sentido, ressalta Luiz Guilherme Marinoni:

O legislador infraconstitucional não está obrigado a estabelecer, para toda e qualquer causa, uma dupla revisão em relação ao mérito, principalmente porque a própria

\footnotetext{
5 Art. 121, § $3^{\circ}$, CF: "São irrecorríveis as decisões do Tribunal Superior Eleitoral, salvo as que contrariarem esta Constituição e as denegatórias de habeas corpus ou mandado de segurança."
} 
Constituição Federal, em seu art. $5^{\circ}$, LXXVIII, garante a todos o direito à tutela jurisdicional tempestiva, direito este que não pode deixar de ser levado em consideração quando se pensa em 'garantir' a segurança da parte através da instituição da 'dupla revisão'. (MARINONI, 2008, p. 505).

Isto ocorre porque o sistema constitucional brasileiro prevê uma variada gama de princípios que devem ser analisados em determinada circunstância, ora prevalecendo uns, ora outros. Como observa Gilmar Ferreira Mendes:

No conflito entre princípios, deve-se buscar a conciliação entre eles, uma aplicação de cada qual em extensões variadas, segundo a respectiva relevância no caso concreto, sem que se tenha um dos princípios como excluído do ordenamento jurídico por irremediável contradição com o outro. (MENDES, 2008, p. 284).

Dessa forma, devido a esses contornos e limites estabelecidos pela Constituição para recorribilidade dos julgados, há na doutrina um entendimento que considera o duplo grau de jurisdição um princípio, previsto na Constituição, mas não uma garantia constitucional. Nesse aspecto, afirma Cândido Rangel Dinamarco:

Caso isolado de princípio constitucional endereçado ao processo e desprovido do caráter de imperatividade é o chamado princípio do duplo grau de jurisdição. É um princípio sim e, como tal, há de inspirar o legislador ao editar leis e o juiz ao interpretá-las e resolver os casos de dúvida sobre a concreta admissibilidade de algum recurso. Não é uma garantia, porém, dado que a própria Constituição apresenta hipóteses de grau único de jurisdição [...]. (DINAMARCO, 2009, p. 200). ${ }^{6}$

Nessa perspectiva, é possível haver exceções ao princípio do duplo de jurisdição, uma vez que a Constituição apenas faz referência implícita a sua existência como princípio, e não como garantia constitucional. Daí a razão pela qual, observa Nelson Nery Junior (2004), não serem consideradas inconstitucionais algumas leis que restringem o cabimento de recursos, tendo como base o referido posicionamento. O autor cita, por exemplo, o caso da Lei de Execução Fiscal (Lei n ${ }^{\circ}$ 6.830/1980), que não admite acesso aos órgãos recursais em causas abaixo de determinado valor ${ }^{7}$, cabendo recurso para o próprio juiz prolator da sentença ${ }^{8}$; e também a Lei dos Juizados Especiais (Lei $n^{\circ}$ 9.099/95) que determina o cabimento de "recurso" contra a sentença do juiz singular para o próprio Juizado, sem, contudo, falar em apelação para órgão de segundo grau de jurisdição.

Além disso, para alguns autores que defendem o duplo grau apenas como um princípio constitucional, a única vedação existente, quanto à limitação ao cabimento de recurso, é com relação aos recursos, expressamente, previstos e regulados pela Constituição.

\footnotetext{
${ }^{6} \mathrm{O}$ autor entende que as garantias constitucionais são preceitos dotados de sanção, cuja inobservância afeta de algum modo a validade ou eficácia do ato transgressor, o qual não pode prevalecer sobre os imperativos constitucionais (DINAMARCO, 2009, p. 200).

${ }^{7}$ LEF, art. 34, caput: "Das sentenças de primeira instância proferidas em execuções de valor igual ou inferior a 50 (cinqüenta) Obrigações Reajustáveis do Tesouro Nacional - ORTN, só se admitirão embargos infringentes e de declaração.

8 Calmon de Passos está entre os autores que propugna pela inconstitucionalidade do art. 34 da Lei de Execução Fiscal (NERY JUNIOR, 2009, p. 42).
} 
É o caso, por exemplo, do recurso extraordinário e do especial, respectivamente previsto no art. 102, III e 105, III, da Constituição Federal. Assim, observa Nelson Nery Junior,

[...] Não poderá haver limitação ao cabimento do recurso especial ou extraordinário, como era permitido no sistema revogado $\left(\mathrm{CF} / 1969119 \quad \S 1^{\circ}\right)$, porque a atual Constituição Federal não estipulou nenhuma restrição. Os requisitos estão no próprio texto constitucional e somente eles devem ser exigidos do recorrente para que sejam conhecidos os recursos extraordinários e especial. (NERY JUNIOR, 2009, p. 280).

Inclusive, na jurisprudência, em relevante precedente em matéria penal, o STF entendeu que a Constituição Federal de 88, em consonância com as suas antecedentes repúblicas, efetivamente, não erigiu o duplo grau de jurisdição ao status de garantia fundamental (NERY JUNIOR, 2009, p. 283). O caso era de ação penal de competência originária de Tribunal de Justiça e a recorrente pretendia ter reconhecido seu direito de apelação a tribunal superior. Eis trecho da ementa da referida decisão:

I. Duplo grau de jurisdição no Direito brasileiro, à luz da Constituição e da Convenção Americana de Direitos Humanos. 1. Para corresponder à eficácia instrumental que lhe costuma ser atribuída, o duplo grau de jurisdição há de ser concebido, à moda clássica, com seus dois caracteres específicos: a possibilidade de um reexame integral da sentença de primeiro grau e que esse reexame seja confiado a órgão diverso do que a proferiu e de hierarquia superior na ordem judiciária. 2. Com esse sentido próprio - sem concessões que o desnaturem - não é possível, sob as sucessivas Constituições da República, erigir o duplo grau em [...] garantia constitucional, tantas são as previsões, na própria Lei Fundamental, do julgamento de única instância ordinária, já na área cível, já, particularmente, na área penal [...]. ${ }^{9}$ 10

Percebe-se, então, que o próprio modelo jurisdicional previsto na

Constituição Federal afasta a possibilidade de aplicação absoluta do princípio do duplo grau de jurisdição (MENDES, 2008). Assim, ao legislador infraconstitucional é dada a possibilidade de imprimir operatividade ao princípio, restringindo o cabimento dos recursos, já que o duplo grau não é considerado uma garantia constitucional.

No caso do sistema recursal brasileiro, há várias hipóteses que dispensam a aplicação do princípio do duplo grau de jurisdição. Especificamente, no recurso de apelação, por exemplo, existem três hipóteses postas como exceção ao referido princípio: (i) a do art. $515, \S 3^{\circ}$; (ii) a do art. 515, $\S 4^{\circ}$ e (iii) a do art. 517, todas do Código de Processo Civil.

Na hipótese do art. 515, § $3^{\circ}$, do CPC, é possível que o tribunal possa julgar desde logo a lide, sem ter de, previamente, restituir o feito para julgamento pelo primeiro grau

\footnotetext{
9 STF, RO em HC 79.785-7-RJ, Rel. Ministro Sepúlveda Pertence, Pleno, julgado em 29.3.2000, DJ 22.11.2002, p. 57.

10 Cabe ressaltar, entretanto, que o Brasil é signatário do pacto de San José da Costa Rica, que prevê expressamente o duplo grau de jurisdição na esfera penal, em seu artigo $8^{\circ}$, inciso II, alínea H. Assim, no processo penal, o duplo grau de jurisdição "é irrestrito e será inconstitucional toda disposição de lei ordinária que restringir ou não permitir a recorribilidade das sentenças [...].” (NERY JUNIOR, 2004, p. 42). O que se quis mostrar, com a decisão acima, é que, também na jurisprudência, existe decisão no sentido de não considerar o princípio do duplo grau uma garantia constitucional absoluta, no âmbito do direito processual civil.
} 
de jurisdição. Basta que a causa verse questão exclusivamente de direito e esteja em condições de imediato julgamento. Somente, portanto, quando as partes não tiverem mais alegações ou provas a serem produzidas, que possam influir no convencimento do Judiciário, tem-se por aplicável o dispositivo em questão (MARINONI, 2008, p. 535). Isso porque o retorno dos autos ao primeiro grau é desnecessário, restando em simples alongamento da tramitação processual, uma vez que o tribunal está antecipando o que julgaria caso mandasse o juiz decidir a causa e ficasse à espera da apelação que o vencido viesse a interpor contra sentença proferida (DINAMARCO, 2002, p. 160-161 apud WAMBIER, 2002, p. 141).

$\mathrm{Na}$ outra hipótese de exceção ao princípio do duplo grau de jurisdição no recurso de apelação, o art. 515, $\S 4^{\circ}$, do CPC, o tribunal, verificando a ocorrência de nulidade sanável, poderá intimar as partes para regularização do feito com a eliminação do vício, sendo possível, após isso, prosseguir no julgamento da apelação. Isto evita novamente o retorno da lide ao primeiro grau para efetuar a correção do vício e proferir nova decisão, provendo agilidade e celeridade aos processos.

Por fim, cabe lembrar a hipótese prevista no art. 517, do CPC, de que a apelação permite a apresentação ao tribunal de questões de fato, não propostas no juízo a quo, caso a parte prove que deixou de oferecê-las, no juízo inferior, por motivo de força maior. Nessa hipótese, ressalta Marinoni (2008), o tribunal, também, passa a ser o primeiro grau de jurisdição, analisando fato inédito para a causa não suscitado no trâmite processual por questões alheias à vontade do litigante (MELLO, 2010, p. 212), dispensando o duplo grau.

Nesses casos específicos, o duplo grau de jurisdição é dispensado, o que não conflita com a natureza constitucional do princípio, não obstante o ordenamento jurídico brasileiro, a exemplo de outros ordenamentos, possibilitar que a decisão emanada do juiz possa estar sujeita a revisão por outro órgão jurisdicional. 


\section{O PRINCÍPIO DO ACESSO À JUSTIÇA}

\subsection{NOÇÕES INTRODUTÓRIAS SOBRE O ACESSO À JUSTIÇA}

Conscientes da necessidade da tutela jurisdicional institucionalizada, como fator de paz na sociedade, os ordenamentos jurídicos democráticos asseguram a proteção judicial efetiva contra qualquer forma de lesão ou de ameaça a direito. Tal fórmula é apresentada como o princípio da inafastabilidade do controle jurisdicional, também conhecido como princípio do direito de ação, ou ainda, do acesso à justiça. No Brasil, o ponto de partida é o estudo do art. $5^{\circ}$, inciso XXXV, da Constituição Federal, dele se extraindo a garantia do direito de ação e do processo, o princípio do juiz natural e todos os respectivos corolários relacionados ao efetivo exercício da tutela jurisdicional (WATANABE, 2000, p. 27).

Segundo Rogério Licastro Torres (2010, p. 29), tradicionalmente, o princípio da inafastabilidade do controle jurisdicional ou do acesso à justiça é formulado em duas acepções. Na primeira acepção, o princípio em referência diz que "qualquer espécie de conflito que se estabeleça em determinadas relações jurídicas tem sua solução confiada ao Estado, em termos de (i) dicção de direitos e (ii) aplicação coativa destes". Em uma segunda acepção, o autor mostra que o princípio do acesso à justiça consigna que o poder judiciário, uma vez instado a exercer sua atividade jurisdicional, não pode deixar de cumpri-la. Sobre essa segunda acepção, José Afonso da Silva (2000, p. 434), ainda, acrescenta que a Constituição não mais qualifica um direito de individual, quando se invoca a atividade jurisdicional nas situações de lesão, ou ameaça, a um direito, seja este individual ou não.

Dessa concepção clássica do princípio do acesso à justiça, percebe-se que são impressas definições pautadas em aspectos nos quais não consideram a qualidade da atividade jurisdicional. Não se considera que o referido princípio - apesar de figurar como verdadeira cobertura geral do sistema de direitos, destinado a atuar sempre que haja alguma ameaça ou lesão de direitos - sofre limitações, tanto legítimas, quanto ilegítimas (DINAMARCO, 2009, p. 115), advindas de barreiras internas e externas do sistema processual como um todo.

Dinamarco (2009) mostra que, nos ordenamentos jurídicos há legítimas limitações ditadas pela Constituição e pela lei ao exercício da jurisdição, como fatores de racionalidade e de realismo no sistema, ao passo que, ao lado dessas limitações existem outras 
que não são legítimas e concorrem para impedir que o sistema processual cumpra de forma adequada e integral sua função de pacificar pessoas e fazer justiça. $\mathrm{O}$ autor ressalta que se trata de fatores vindos das imperfeições advindas da própria lei processual, bem como de fatores residentes na realidade política, social, econômica e cultural na qual o processo se destina a servir. Assim, o autor destaca:

Da lei vêm defeitos como a extrema burocracia dos serviços judiciários e pequena abrangência dos julgamentos, com causas que se repetem às centenas e congestionam os juízos e tribunais [...]. Da realidade econômica vem a insuficiência de recursos das pessoas carentes para custear o litígio sem prejuízo da subsistência, associada à precariedade dos serviços de assistência judiciária. Da realidade cultural da nação vem a desinformação e, o que é pior, a descrença nos serviços judiciários [...]. (DINAMARCO, 2009, p. 116).

Dessa forma, tendo em vista esses fatores ilegítimos limitativos, os quais alguns deles foram citados acima, observa-se que apenas a previsão constitucional do acesso à justiça não é suficiente para concretizar os objetivos do Estado, mais precisamente da jurisdição e do processo, o que fez surgir, em vários países, movimentos voltados à atualização do conceito do acesso à justiça. Falam Cappelletti e Garth (1988, p. 31) em três movimentos renovatórios em torno do conceito de acesso à justiça, que tiveram início na metade da década de 1960 e desenvolveram-se, mais ou menos, em sequência cronológica.

O primeiro movimento foi voltado para a questão da assistência judiciária integral aos necessitados. Houve o entendimento de que a existência de uma estrutura jurisdicional estatal não é capaz, por si mesma, de concretizar o acesso à justiça para uma considerável camada da população, especificamente os mais pobres, na acepção jurídica da palavra (MESQUITA, 2008, p. 160).

Essa preocupação desencadeou reformas judiciárias em vários países, sobretudo no curso das décadas de 1960 e 1970 (CAPPELLETTI; GARTH,1988). No Brasil, especificamente, a preocupação em disciplinar a assistência judiciária teve como marco histórico a Lei $\mathrm{n}^{\mathrm{o}}$ 1.060/50, ainda em vigor, que garantiu aos jurisdicionados, sob determinadas condições, o benefício da assistência judiciária. Além disso, a Constituição de $1988^{11}$ fixou, expressamente, no art. $5^{\circ}$, inciso LXXIV, a garantia da assistência jurídica integral e gratuita aos que comprovarem insuficiência de recursos, confirmando de forma clara a relevância da questão.

Contudo, constatou-se que o acesso à justiça apenas voltado à proteção de direitos individuais era insuficiente. Essa percepção fez surgir, em torno da questão do acesso

\footnotetext{
11 A disciplina também alcançou o nível constitucional, com a inserção da assistência judiciária nas Cartas de 1934 (art. 112 , $\$ 32$ ), de 1946 (art. 141, § 35), de 1967 (art. 150, § 32) e a Emenda Constitucional nº 1, de 1969 (art. 153, § 32) (ROSSI; MESQUITA, 2008, p. 161).
} 
à justiça, o segundo movimento renovatório ${ }^{12}$, agora com o foco voltado à abrangência de certos conflitos envolvendo interesses de grupos ou mesmo toda uma coletividade. Houve a necessidade de considerar a importância da tutela de direitos e interesses difusos e coletivos, devido ao "aumento na complexidade das relações jurídicas no campo econômico e a inaptidão das regras do processo civil tradicional em solucionar efetivamente estes conflitos de massa". (MESQUITA, 2008, p. 162). Viu-se que os institutos processuais precisavam de uma reformulação para que grupos ou mesmo toda a coletividade tivessem seus direitos tutelados, tendo como instrumento o processo, sem a necessidade de acionamento do Estado pelos sujeitos individualmente considerados.

No caso brasileiro, a Constituição de 1934 trouxe a primeira hipótese de alguém, legitimamente, defender em juízo direito alheio. Essa possibilidade foi tratada pela doutrina sob a denominação de ação popular, que não foi consagrada pela Constituição de 1937, retornando em 1946 e em todas as Constituições posteriores (MESQUITA, 2008, p. 162). Também, como reflexo do segundo movimento de acesso à justiça, no Brasil, houve a instituição da ação civil pública e da ação coletiva para tutela dos valores ambientais e do consumidor (DINAMARCO, 2009, p. 116), dentre outras medidas, cujo objetivo é a defesa de direitos, que, muito provavelmente, não são reclamados pelos titulares individuais.

Atualmente, entende-se que esteja ocorrendo o terceiro movimento em torno da questão do acesso à justiça, cuja principal preocupação foca-se no aperfeiçoamento técnico dos mecanismos internos do processo (DINAMARCO, 2009). Passa-se a entender a questão do acesso à justiça não apenas pela facilitação do acesso aos órgãos jurisdicionais e a atuação finalística do Estado por meio da sentença, mas da efetiva concretização do que nela esteja determinado (MESQUITA, 2008, p. 164). Como observam Cappelletti e Garth (1988, p. 6768), esta terceira fase centra sua atenção no conjunto de instituições e mecanismos, pessoas e procedimentos utilizados para processar e prevenir disputas na sociedade moderna. De acordo com os autores, o método dessa fase não consiste em abandonar as técnicas aplicadas nos dois primeiros movimentos, mas em tratá-las como algumas de uma série de possibilidades a serem utilizadas para melhoria do acesso.

Dessa forma, a concepção tradicional do conceito de acesso à justiça vem cedendo lugar ao enfoque substancial do referido princípio, no sentido de que se considera assegurado o acesso à justiça não apenas quando os jurisdicionados possam acessar a estrutura jurisdicional em termos abstratos, formais, senão também em termos de conteúdo, de

\footnotetext{
${ }^{12}$ Essa fase situa-se cronologicamente no mesmo período em que as preocupações e providências na área da assistência judiciária ocorriam, pelo menos nos Estados Unidos, onde este novo movimento de reforma foi provavelmente mais avançado (CAPPELLETTI; GARTH,1988, p. 49).
} 
efetividade da jurisdição ensejada à sociedade (MELLO, 2010, p. 30). Percebe-se, então, que a questão do acesso à justiça é uma equação muito mais complexa do que se apresenta no texto constitucional, sendo necessária a mudança de sua concepção para que se efetive a necessária tutela jurisdicional.

\subsection{VISÃO CONTEMPORÂNEA DO PRINCÍPIO DO ACESSO À JUSTIÇA}

Feitos os apontamentos introdutórios, percebe-se que a concepção sobre o princípio do acesso à justiça que mais está adequada à realidade atual é a que considera o acesso à justiça não apenas como garantia do direito de invocar o Estado por via da ação, mas também como princípio que assegure ao jurisdicionado aproximar-se e usufruir de jurisdição qualitativamente boa, o mais próximo possível da jurisdição justa (MELLO, 2010, p. 31). O direito ao acesso à proteção judicial não pode significar essencialmente o direito formal de o indivíduo agravado propor ou contestar uma ação. Isso porque o acesso formal, mas não efetivo, à justiça, corresponde à igualdade apenas formal, mas não efetiva à tutela jurisdicional (CAPPELLETTI e GARTH, 1988, p. 9).

A noção acima transcrita leva em conta que a sociedade atual não mais se satisfaz com a prestação jurisdicional tão só porque formalmente estão à sua disposição os mecanismos que conduzem ao foro. Evidencia-se que não é suficiente o direito à tutela jurisdicional. É preciso uma tutela adequada (NERY JUNIOR, 2009). Assim, segundo Dinamarco (2009, p. 117), a compreensão contemporânea do conceito de acesso à justiça exige a justaposição de três fatores: (i) a qualidade dos serviços jurisdicionais; (ii) a tempestividade da tutela realizada mediante o processo e (iii) a sua efetividade. Como observa o autor,

Isso significa que não basta alargar o âmbito de pessoas e causas capazes de ingressar em juízo, sendo também indispensável aprimorar internamente a ordem processual, habilitando-a a oferecer resultados úteis e satisfatórios aos que se valem do processo. (DINAMARCO, 2009, p. 117).

Nessa perspectiva, o princípio do acesso à justiça é observado e entendido sob o enfoque da instrumentalidade do processo, tendo em vista o resultado concreto que a atividade jurisdicional pode produzir para aquele que busca uma determinada tutela. Nesses termos, destaca Bedaque (2002, p. 14), “daí falar-se no processo équo e justo, ou seja, aquele instrumento apto a assegurar efetivamente os direitos estabelecidos no ordenamento jurídico material." 
Portanto, acesso à justiça, atualmente, é considerado como acesso à ordem jurídica justa. É o oferecimento de justiça substancial.

Além disso, para que se tenha o oferecimento de justiça substancial, acrescenta Dinamarco (2009), o ordenamento jurídico deve atender ao trinômio qualidade, tempestividade e efetividade. Não há o acesso à justiça quando sequer se consegue o exame de suas pretensões pelo poder judiciário, ou quando se recebem soluções atrasadas ou mal formuladas ou quando não há, no campo prático, efetivação dos provimentos judiciais (DINAMARCO, 2009, p. 118).

A propósito, a própria garantia constitucional da ação torna-se inoperante sem o tratamento adequado para o exame de uma determinada pretensão. É preciso, por exemplo, que, na preparação do exame substancial da pretensão, as partes sejam tratadas com igualdade, participem de maneira regular e que o juiz não se omita na condução do processo, tudo isso com a finalidade de que o julgamento da causa ofereça uma tutela adequada (Dinamarco, 2009). São alguns dos contornos do denominado processo justo, ou processo équo, que é composto pela efetividade de um mínimo de garantias de meios e de resultados (DINAMARCO, 2009, p. 118).

Vale registrar que - devido ao clamor por um sistema processual mais eficiente e capaz de atender ao trinômio qualidade, tempestividade e efetividade - se processaram várias reformas legislativas no Código de Processo Civil, especialmente mediante leis aprovadas a partir do ano de 1994. Essas medidas buscavam "agilizar a tramitação dos feitos cíveis e tornar efetivas as decisões judiciais" (MESQUITA, 2008, p. 167). Só a título de exemplo, destaca-se a previsão da chamada tutela jurisdicional antecipada, prevista no art. 273, do CPC, e a medida prevista para acelerar a execução da sentença, presente no art. 475-J, também do CPC. Além disso, houve a edição de normas não contidas no Código de Processo Civil que igualmente contribuíram para o propósito da melhoria do acesso à justiça e da efetividade da jurisdição, como, por exemplo, a instituição dos Juizados Especiais Cíveis e Criminais e a reestruturação da arbitragem com a Lei $n^{\circ}$ 9.307/96 (MESQUITA, 2008).

Também, é preciso ressaltar, que a concepção contemporânea do acesso à justiça pode ser dimensionada sob vários aspectos, sendo todos esses importantes para se entender o conceito sobre um determinado enfoque. Segundo Kazuo Watanabe, esses aspectos são os seguintes:

a) aspecto processual propriamente dito, referente à facilitação do acesso Judiciário; b) aspecto processual-social, referente a ações que instrumentalizam de forma peculiar o acesso ao Judiciário (as conhecidas 'ações constitucionais'); c) aspecto 
material-social, referente às condições materiais que as pessoas têm, sua influência na vida de tais pessoas e às demandas propostas em face dessas condições sociais; d) aspecto valorativo-constitucional, que indica a necessidade de o Judiciário se submeter aos valores constitucionalmente superiores. (WATANABE, 1988, p. 135 apud MESQUITA, 2008, p. 165).

Dessa forma, o conceito de acesso à justiça abarca uma série de direitos: à informação e ao conhecimento do direito substancial; à pesquisa permanente sobre a adequação entre a ordem jurídica e a realidade sócio-econômica do país; aos instrumentos processuais capazes de promover a efetiva tutela dos direitos, dentre outros direitos (MESQUITA, 2008, p. 165). Todos eles convergentes para essa promessa-síntese que é a garantia do acesso à justiça. Assim, como observa Cândido Rangel Dinamarco,

\begin{abstract}
A Constituição formula princípios, oferece garantias e impõe exigências em relação ao sistema processual com um único objetivo final, que se pode qualificar como garantia-síntese e é o acesso à justiça [...]. A efetividade dessas disposições constitui penhor da (relativa) universalização da tutela jurisdicional ${ }^{13}$, com a desejada redução dos resíduos não-jurisdicionalizáveis, bem como do aprimoramento do processo mesmo e de seus resultados, segundo os parâmetros do processo justo e équo. (DINAMARCO, 2009, p. 203).
\end{abstract}

Como interessa ao presente estudo, vale ressaltar que foi nessa perspectiva que a Emenda Constitucional $n^{\circ} 45$ acrescentou ao rol dos direitos fundamentais, previstos na Constituição Federal, o inciso LXXVIII: "a todos, no âmbito judicial e administrativo, são assegurados a razoável duração do processo e os meios que garantam a celeridade de sua tramitação". Segundo Nelson Nery Junior (2009, p. 311), trata-se de um dos desdobramentos do princípio do acesso à justiça presente na Constituição $\left(\mathrm{CF}, \operatorname{art.} 5^{\circ}, \mathrm{XXXV}\right)$.

Nesse passo, a Constituição brasileira adotou, expressamente, a duração razoável do processo e da celeridade processual como princípios constitucionais, tendo em vista o direito que todos têm de obter do poder judiciário uma tutela jurisdicional adequada. Passemos, com isso, à análise dos referidos princípios.

\title{
2.3 O PRINCÍPIO DA CELERIDADE E DA DURAÇÃO RAZOÁVEL DO PROCESSO E DO ACESSO À JUSTIÇA
}

Sabe-se que, para plenitude do acesso à justiça, uma das medidas necessárias é a remoção dos males resistentes à universalização da tutela jurisdicional

\footnotetext{
13 Segundo Dinamarco (2009, p. 116), “universalizar a jurisdição é endereçá-la à maior abrangência factível, reduzindo racionalmente os resíduos não-jurisdicionalizáveis", ou seja, que o universo de situações litigiosas possa ser canalizado ao processo para efetividade das promessas de tutela jurisdicional presentes na Constituição.
} 
(DINAMARCO, 2009, p. 117). Essa medida tem como objetivo tornar o acesso à justiça mais rápido e capaz de oferecer soluções justas e efetivas.

Contudo, é certo que alguns dos problemas existentes no sistema processual são insuperáveis, sendo possível apenas a redução, mas não a eliminação deles (DINAMARCO, 2009, p. 144). É o caso do problema da duração dos processos, que eterniza litígios e prolonga as angústias dos litigantes. Como observa Gilmar Ferreira Mendes,

A duração indefinida ou ilimitada do processo judicial afeta não apenas e de forma direta a idéia de proteção judicial efetiva, como compromete de modo decisivo a proteção da dignidade da pessoa humana, na medida em que permite a transformação do ser humano em objeto dos processos estatais. (MENDES, 2008, p. 500).

Nesse contexto, como visto no tópico acima, a Constituição Federal elegeu tanto a necessidade da duração razoável do processo quanto a celeridade da sua tramitação no rol dos direitos fundamentais ( $\mathrm{CF}$, art. $5^{\circ}$, inciso LXXVIII), tendo em vista a efetividade da tutela jurisdicional. Assim, no sistema processual brasileiro, surgiram várias manifestações legislativas que se traduzem em meios de celeridade do processo, bem como de lhes proporcionar a duração razoável ${ }^{14}$ (NERY JUNIOR, 2009, p. 317). É o caso, por exemplo, da criação dos juizados especiais cíveis e criminais; da possibilidade de utilização dos meios alternativos de solução dos conflitos, tendo como exemplo a Lei da arbitragem; da simplificação do procedimento do recurso de agravo, previsto no art. 522, do CPC; da criação do processo eletrônico, entre outras medidas (NERY JUNIOR, 2009).

Nelson Nery Junior (2009, p. 314) mostra que o princípio da duração razoável do processo desempenha dupla função no sistema jurídico processual. De um lado, diz respeito ao tempo do processo em sentido estrito, ou seja, a duração que o processo tem desde seu início até o final com o trânsito em julgado, administrativo ou judicial. De outro lado, o princípio refere-se à adoção de meios alternativos de solução de conflitos, que proporcionam aliviar a carga de trabalho da justiça ordinária, contribuindo para abreviar a duração média de determinado processo.

Além disso, conforme o autor supracitado, a razoabilidade da duração do processo deve ser aferida mediante critérios objetivos. Isso porque cada hipótese concreta adquire certas particularidades, que são específicas para aquele determinado caso. Segundo ainda o mesmo autor, esses critérios são: a natureza e complexidade da causa; o comportamento das partes e de seus advogados; a atividade e o comportamento das

\footnotetext{
14 Todavia, é de se ressaltar que a questão da duração razoável do processo e da celeridade de sua tramitação não se resume apenas a mudanças legislativas. Segundo Gilmar Mendes (2008, p. 500), o assunto envolve temas complexos e pretensões variadas, como a criação de órgãos judiciais em número adequado, o controle da prestação jurisdicional do poder público, em particular do poder judiciário; entre outros temas, que não serão objetos do presente estudo.
} 
autoridades competentes, tanto no âmbito judiciário, quanto no administrativo e, por fim, a fixação de prazos para prática de atos do processo que assegure, sobretudo, o direito ao contraditório e à ampla defesa (NERY JUNIOR, 2009, p. 315).

Para citar alguns exemplos, Nelson Nery Junior (2009, p. 316) mostra que a complexidade da causa pode fazer com que se exija uma dilação probatória, como uma perícia múltipla, fazendo com que a duração do processo para determinado caso seja maior do que a de um caso simples. Outro exemplo diz respeito ao comportamento das partes durante o andamento do processo. Exige-se certa diligência das partes para prática de atos que estejam a seu cargo.

Ademais, deve-se ter em mente, quando se analisa a questão da razoabilidade da duração do processo, que todo movimento de agilização encontra limites legitimamente estabelecidos, que levam o construtor do sistema processual a estabelecer o racional equilíbrio possível entre duas exigências antagônicas. Segundo Dinamarco (2009, p. 145), de um lado a exigência da celeridade processual, de outro, da ponderação no trato da causa e das razões expostas pelos litigantes. Seguindo no seu raciocínio, todo o sistema processual é pautado pelo indispensável convívio entre normas tendentes a agilizá-lo e normas que lhe impedem a excessiva aceleração (DINAMARCO, 2009, p. 146). Nesse sentido, ressalta o autor,

São dois valores conhecidos o da segurança das relações jurídicas, responsável pela tranqüilidade que sempre contribui para pacificar (e isso aconselha celeridade); e o da justiça nas decisões, que também é inerente ao próprio escopo fundamental do sistema processual (pacificar com justiça). Como é muito difícil fazer sempre bem o que se consegue fazer logo, impõe-se como indispensável o equilíbrio entre as duas exigências, com renúncia a radicalismos [...]. (DINAMARCO, 2009, p. 145).

Nessa perspectiva, Barbosa Moreira (1995, p. 171 apud CEI, 2009, p. 227) destaca que o processo deve ter duração razoável, mas sempre respeitando as garantias orgânicas e processuais, como contraditório e a ampla defesa, a igualdade entre as partes, entre outros valores. Em idêntica orientação, Nelson Nery Junior afirma que a busca da celeridade e razoável duração do processo devem ser analisados e ponderados juntamente com outros valores e direitos constitucionais fundamentais, sobretudo o direito ao contraditório e à ampla defesa (NERY JUNIOR, 2009, p. 318).

Da visão dos referidos autores, ressoa claro que a efetividade do processo, proporcionando uma tutela jurisdicional adequada, não se traduz somente em celeridade, bem como na sua duração razoável, mas está vincula também à ponderação no trato dos litígios, que está relacionada à justiça da decisão. Isso porque a celeridade não é valor absoluto, que deve ser respeitado a qualquer custo. Também não é a segurança valor absoluto, uma vez que 
a necessidade de se esgotar todas as possibilidades, mesmo que mínimas, não é algo razoável. Deve haver equilíbrio entre esses valores (CEI, 2009, p. 226).

Assim, reafirmando a ideia de Dinamarco (2009, p. 146), observa-se que, no sistema processual civil, há tanto meios aceleratórios do procedimento judicial quanto normas que impedem a maior celeridade, tendo em vista o objetivo de propiciar um julgamento melhor da causa e, consequentemente, a preservação dos direitos dos litigantes. No primeiro grupo, tem-se como exemplo as medidas antecipatórias, entre estas as cautelares, a tutela antecipada e a execução provisória, que possibilitam evitar a corrosão da tutela jurisdicional pelos males causados pelo decorrer do tempo. Já no grupo de medidas que impedem a maior celeridade, podem-se citar, como exemplo, as normas que instituem os recursos, proporcionando reexame da causa ou de incidentes a ela inerentes (Dinamarco, 2009, p. 146).

Portanto, apesar de a celeridade processual e de a razoável duração do processo não terem o caráter de princípios absolutos, a prestação jurisdicional em prazo razoável é indissociável da proteção judicial efetiva, ou seja, do efetivo acesso à justiça. Isso porque o princípio do acesso à justiça é a síntese de todos os princípios e garantias previstos no ordenamento jurídico. Como ressalta Dinamarco, ao falar das garantias processuais inerentes a uma ordem jurídica,

[...] as garantias do ingresso em juízo, do devido processo legal, do juiz natural, da igualdade entre as partes - todas elas somadas visam a um único fim, que é a síntese de todas e dos propósitos integrantes no direito processual constitucional: o acesso à justiça. Uma vez que o processo tem por escopo magno a pacificação com justiça, é indispensável que todo ele se estruture e seja praticado segundo essas regras voltadas a fazer dele um canal de condução à ordem jurídica justa. (DINAMARCO, 2008, p. 361).

Nesse sentido, o acesso à justiça abrange uma série de outros princípios processuais, inclusive o da celeridade e o da duração razoável do processo, que, somados e aplicados no processo estruturado segundo esses preceitos, levam, como consequiência, à efetiva tutela jurisdicional.

A partir dessa ideia, a interpretação do art. $5^{\circ}$, inciso LXXVIII, da Constituição Federal, deve ser dada à luz do princípio do acesso à justiça, previsto, no inciso XXXV, daquele artigo. Mesmo porque não há acesso efetivo à justiça se não há tutela jurisdicional oferecida em tempo razoável. 


\section{A SÚMULA IMPEDITIVA DE RECURSOS}

\subsection{A LEI No 11.276/2006 E O ART. 518, § $1^{\circ}$ DO CPC}

Como foi visto, a grande tendência do processo civil moderno é de orientar-se para resultados práticos, a fim de viabilizar a realização do direito substancial e do acesso à justiça, com economia processual e celeridade. Em vista disso, surgiram alguns comportamentos paliativos, como a diminuição do número de instâncias processuais e a adoção de procedimentos urgentes, pois, apesar do elevado grau de verdade real que se obtinha com ultrapassado procedimento, perdia-se em efetividade e, principalmente, na tutela e entrega adequada do bem da vida pretendido.

Nesse contexto, com o fim de propiciar maior acesso à justiça, por meio de uma razoável duração do processo, o legislador brasileiro passou a imprimir mudanças procedimentais, criou novos filtros e mecanismos que conferem maior agilidade aos trâmites processuais. Assim, foi incorporado ao nosso ordenamento jurídico, dentre outros com o mesmo escopo de agilidade processual, o instituto da súmula impeditiva de recurso, implementada no artigo 518, $\S 1^{\circ}$, do Código de Processo Civil, por meio da lei $\mathrm{n}^{\mathrm{o}}$ $11.276 / 2006$.

Trata-se, na perspectiva de outras tantas alterações no sistema processual civil, de mais uma modificação desencadeada pela morosidade da justiça e pela falta de efetividade do processo. Segundo o $\S 1^{\circ}$ do art. 518, “o juiz não receberá o recurso de apelação quando a sentença estiver em conformidade com súmula do Superior Tribunal de Justiça ou do Supremo Tribunal Federal."

De acordo com Rogério Licastro Torres de Mello (2010, p. 213), o dispositivo criado "é mais umas das inovações processuais civis, cujo escopo declarado é o de acelerar o trâmite processual mediante restrições do procedimento das vias impugnativas das decisões judiciais, por meio da utilização dos precedentes sumulados das cortes excepcionais [...]”. Assim, se a sentença apenas reitera o entendimento contido em súmulas do Superior Tribunal de Justiça ou do Supremo Tribunal Federal, não há razão para admitir que a parte interponha recurso com argumentos já consolidados nos citados tribunais. Isso porque, além de tal medida estar em conformidade com o sistema adotado com a súmula vinculante (CEI, 2009, p. 202), Marinoni (2008, p. 532) afirma que a abertura de uma livre oportunidade para interposição da apelação não só traz prejuízo ao direito fundamental à duração razoável do 
processo, como também proporciona um acúmulo desarrazoado de recursos e processos nos tribunais, notadamente nos casos de "ações repetitivas". Segundo o autor,

É incontestável que a interposição exagerada de recursos resulta na lentidão do serviço jurisdicional e, portanto, aprofunda a crise do Judiciário, que tem o grave compromisso de atender ao direito constitucional de todo cidadão a uma resposta jurisdicional tempestiva. (MARINONI, 2008, p. 532).

Além disso, observa a doutrina, parece razoável que as sentenças em conformidade com os entendimentos sumulados sejam irrecorríveis, caso seja entendido que as súmulas já foram alvo de discussão prévia em diversos outros casos submetidos a intenso contraditório e a exame de diversos tribunais (CÂMARA, 2008, p. 80). Nesse sentido, ressalta Cassio Scarpinella Bueno (2006, p. 35), que o $\S 1^{\circ}$ do art. 518 do CPC tem tudo para ser entendido como regra de racionalização de julgamentos, na medida em que sua aplicação reiterada observe, sempre, um prévio e exaustivo contraditório das questões a serem sumuladas pelos tribunais superiores e que os levem à edição das súmulas respectivas.

Dessa forma, o objetivo da regra é impedir o cabimento da apelação quando ela tiver como única intenção, simplesmente, afastar o entendimento sumulado pelo Supremo Tribunal Federal ou pelo Superior Tribunal de Justiça, que foi aplicado na sentença pelo magistrado (MARINONI, 2008, p. 533). Cabe ponderar, todavia, que, se a súmula é apenas um dos argumentos utilizados na sentença, não se estará propriamente diante de sentença em conformidade com súmula, não havendo espaço para negativa de trânsito ao recurso de apelação, desde que o outro fundamento seja objeto de impugnação (BUENO, 2006, p. 38).

\subsection{JUÍZO DE ADMISSIBILIDADE OU MÉRITO RECURSAL?}

O recurso, como já analisado, tem como função primordial o reexame de decisão judicial, sendo um procedimento em continuação, pelo fato de ocorrer dentro do mesmo processo (NERY JUNIOR, 2004, p. 252). No entanto, para o exame do mérito dos recursos, é necessário que estejam presentes determinados requisitos. A análise da existência desses requisitos é o que se chama de juízo de admissibilidade.

O objeto do juízo de admissibilidade, isto é, a matéria que deve ser verificada na fase de admissibilidade do recurso, a fim de que se possa julgar o mérito, são os pressupostos de admissibilidade dos recursos. De acordo com a classificação adotada por Barbosa Moreira (2003, p. 252 apud NERY JUNIOR, 2004, p. 273), esses pressupostos dividem-se em: requisitos intrínsecos e extrínsecos. 
Segundo Nelson Nery Junior (2004, p. 274), os requisitos intrínsecos levam em conta o conteúdo e a forma da decisão impugnada, tomando-se o ato judicial impugnado no momento e da maneira como foi prolatado. Deles fazem parte o cabimento, a legitimação para recorrer e o interesse em recorrer. Já os requisitos extrínsecos, de acordo com o referido autor, dizem respeito aos fatores externos à decisão que se pretende impugnar, não sendo relevantes os dados que compõem o conteúdo da decisão impugnada (NERY JUNIOR, 2004, p. 274). São eles a tempestividade, a regularidade formal, a inexistência de fato impeditivo ou extintivo do direito de recorrer e o preparo.

O exame dessas condições de admissibilidade é necessário para que o juízo ad quem possa proferir o julgamento do mérito do recurso. "O juízo de mérito é o juízo em que se apuram os fundamentos do recurso" (CEI, 2009, p. 203), ou seja, é o momento de "saber se o recorrente tem ou não razão quanto ao objeto do recurso" (NERY JUNIOR, 2004, p. 252). Nessa lógica, o juízo de admissibilidade dos recursos, cronologicamente, antecede o exame do mérito, justamente por serem requisitos de admissibilidade do julgamento deste. Ele é formado por questões prévias, que vão possibilitar ou não o exame do mérito do recurso.

No caso da apelação, o juízo de admissibilidade é, ao menos em tese, de competência definitiva do órgão ad quem. Ocorre que, para facilitar os trâmites procedimentais, em atendimento ao princípio da economia processual, o exame dos requisitos de admissibilidade do recurso também é realizado pelo juízo de origem, que decidirá provisoriamente sobre sua admissibilidade (NERY JUNIOR, 2004, p. 255).

De todo modo, essa decisão proferida pelo juízo a quo poderá ser alterada pelo tribunal, uma vez que a ele compete, como afirmado, o juízo de admissibilidade definitivo. $\mathrm{O}$ órgão ad quem não fica vinculado ao juízo de admissibilidade positivo proferido no primeiro grau de jurisdição, tampouco ao negativo, pois, neste último caso, a decisão prolatada pelo órgão a quo está sujeita a impugnação para que o tribunal ad quem decida sobre a questão. Portanto, seja como for a decisão do juízo de origem, ela poderá ser alterada pelo tribunal, tanto pelo prosseguimento normal da apelação, quanto pela interposição de recurso para impugnar decisão que negou seguimento à apelação (CEI, 2009, p. 203).

Cabe frisar, ainda, que o juízo de admissibilidade é matéria de ordem pública. O juiz ou o tribunal deverá examinar os requisitos independentemente de provocação, ou seja, de ofício, para que se evitem decisões inúteis e o prosseguimento desnecessário do processo, haja vista que as matérias de ordem pública, assim como os requisitos de admissibilidade, não precluem (CEI, 2009, p. 203). Assim, mesmo no caso da decisão de não recebimento de recurso de apelação na origem ter sido reformada pelo tribunal, por intermédio da 
interposição do agravo de instrumento, como será visto em outro momento deste trabalho, poderá o mesmo tribunal, quando da análise da apelação, rever sua decisão, não ficando vinculado à decisão do agravo, justamente por se tratar de matéria de ordem pública (CEI, 2009, p. 203).

Além disso, também cabe ressaltar, que o juízo de admissibilidade, tanto negativo, quanto positivo, é declaratório (NERY JUNIOR, 2004, p. 266). A decisão em que o juiz ou tribunal declara admissível, ou não, um recurso, apenas declara situação preexistente, uma vez que no momento de sua interposição devem ser cumpridos todos os requisitos exigidos (CEI, 2009, p. 204).

Dessa natureza declaratória do juízo de admissibilidade, depreende-se o efeito ex tunc da decisão sobre a admissibilidade ${ }^{15}$. Assim, observa Nelson Nery Junior (2004, p. 267), o recurso não conhecido, por falta de qualquer requisito de admissibilidade, faz com que ocorra o trânsito em julgado da decisão impugnada no momento em que se verificou o não conhecimento do recurso, e não no momento em que o órgão ad quem proferiu o juízo de admissibilidade negativo.

A súmula impeditiva de recursos, pela redação da lei e pelo modo e tempo processual em que se procede, aparenta ser um requisito de admissibilidade. Com esses destaques, alguns autores entendem o instituto como mais um requisito de admissibilidade recursal.

Antonio Dall'Agnol Junior (2006, p. 183 apud DONOSO, 2007, p. 35), ao tratar do tema, pondera que a súmula impeditiva é uma especificidade da falta do interesse de recorrer, não havendo a criação de um novo requisito de admissibilidade.

Em sentido idêntico, Cassio Scarpinella Bueno afirma que o art.518, § $1^{\circ}$, do CPC, é um requisito de admissibilidade do recurso, embora, ressalve-se, ele não o relacione ao interesse recursal (DONOSO, 2007, p. 35). De acordo com seu entendimento, a súmula impeditiva é considerada um requisito de admissibilidade, pois: (i) a parte poderá recorrer do não-recebimento do recurso; (ii) se o juízo a quo procedesse ao exame de mérito, haveria ofensa ao modelo constitucional do processo civil e (iii) a própria lei se refere ao nãorecebimento do recurso, expressão que causa o entendimento de que o legislador tratou a hipótese como requisito de admissibilidade, e não como juízo de mérito recursal (BUENO, 2006, p. 39).

\footnotetext{
${ }^{15}$ Há controvérsias sobre o tema. Barbosa Moreira, Nelson Nery, Luiz Fux entendem que o efeito é ex tunc, posição adotada neste trabalho, Tereza Arruda Alvim Wambier entende pelo efeito ex nunc, Flávio Cheim Jorge tem posição intermediária, que inclusive já foi defendida em decisão do STJ (CEI, 2009, p. 204).
} 
Todavia, apesar dos argumentos anteriormente expostos, e não deixando de reconhecer a pertinência deles, o fato é que a súmula impeditiva apresenta características diversas do que se costuma tratar por requisito, posto que indagar se a sentença está ou não em consonância com o entendimento dos tribunais superiores é questão relacionada ao mérito do recurso (WAMBIER; ALMEIDA; TALAMINI, 2006, p. 519). Como observa Tesheiner (2006, p. 204), “com a Lei $n^{o} 11.276 / 2006$, ao juiz será dado examinar o conteúdo de sua própria sentença frente às súmulas do Superior Tribunal de Justiça e do Supremo Tribunal Federal e, consequentemente, o próprio conteúdo do recurso interposto [...]". Quando o juízo ad quem recebe o recurso, ele antes fará a análise dos requisitos de admissibilidade do recurso e, logo em seguida, passará à análise do pedido do recorrente, de reforma ou anulação da sentença. Ao rejeitar seguimento ao recurso com base no art.518, $\S 1^{\circ}$, do CPC, o juiz a quo enfrenta justamente este último ponto, ou seja, o da não possibilidade de reforma ou anulação da sua decisão, porque uma súmula do Superior Tribunal de Justiça ou do Supremo Tribunal Federal indica que o julgamento foi adequado (DONOSO, 2007, p. 36).

Além disso, a supressão de instância não estaria violando o referido modelo constitucional do processo. O juízo a quo não julga a causa no lugar do tribunal, mas simplesmente impede que o recurso chegue ao órgão superior, pois muito provavelmente não haverá provimento de tal recurso se este estiver em consonância com determinada súmula dos referidos tribunais superiores. Como alerta Tesheiner (2006, p. 214), a intenção do legislador com o dispositivo ora em análise foi impedir a interposição de recursos meramente protelatórios, valorizando a jurisprudência sumulada.

No caso, também cabe ressaltar que a aplicação da súmula impeditiva pode se aproximar do disposto no art. 557 do CPC, apresentando características diversas do que se costuma tratar como requisito de admissibilidade. É o que se expõe a seguir.

\subsection{RELAÇÃO COM O ART. 557 DO CPC}

Conforme afirmado acima, pode-se atribuir à súmula impeditiva de recurso as características do art. $557^{16}$ do CPC, quando compatíveis, por ambos terem a mesma natureza (CEI, 2009, p. 211). Nesse contexto, a súmula passa a ser considerada um adiantamento do referido dispositivo.

\footnotetext{
${ }^{16} \mathrm{O}$ dispositivo trata de provimento a ser proferido, monocraticamente, pelo relator dos recursos nos tribunais, não podendo ser o mesmo pronunciado nos processos de competência originária dos tribunais ou nos demais incidentes que têm seu curso naquelas Cortes (CÂMARA, 2008, p. 135).
} 
A redação do art. 557 do CPC é resultado da tendência do aumento dos poderes do relator com o fim de agilizar o julgamento dos recursos ${ }^{17}$, evitando-se a remessa dos autos ao órgão colegiado e todas as formalidades necessárias para esse intento (CEI, 2009, p.209). Segundo Gilson Delgado Miranda,

Com essa regra, atente-se, não se impede a interposição do recurso, mas desestimula-se o seu não-conhecimento. O que se quis, nesse caso, foi exatamente impor uma antecipação do que fatalmente acontecerá no caso pela atuação do próprio relator do recurso em atenção ao disposto no art. 557 do CPC, tudo em homenagem ao princípio da celeridade. (MIRANDA, 2008, p. 2008 apud CEI, 2009, p. 204).

$\mathrm{O}$ art. 557 do $\mathrm{CPC}$ abre quatro hipóteses em que pode ser aplicado: quando manifestamente inadmissível; improcedente; prejudicado; e em confronto com súmula ou com jurisprudência do respectivo tribunal julgador ou então do Supremo Tribunal Federal e do Superior Tribunal de Justiça. O dispositivo confere poderes ao relator para apreciar a admissibilidade e o mérito dos recursos que são da competência do órgão colegiado (NERY JUNIOR, 2004, p. 272).

Contra decisão proferida pelo relator admite-se agravo interno dirigido ao órgão colegiado do tribunal, previsto no art. 557, $\S 1^{\circ}$, do CPC. Nesse caso, não é aplicável novamente o art. 557 do CPC sob pena de inconsistência do sistema (CEI, 2009, p. 210).

Embora a expressão "negar seguimento" tenha sido usada na redação do art. $557^{18}$ do CPC, o referido dispositivo possibilita o julgamento de mérito dos recursos nas hipóteses de recurso manifestamente improcedente, prejudicado ou em confronto com súmula ou com jurisprudência dominante do respectivo tribunal julgador ou do STF e do STJ. Permite-se, dessa forma, ao relator proferir decisão negativa de mérito, quando se tratar de recurso a que, muito provavelmente, o órgão colegiado competente para apreciá-lo negará provimento (CÂMARA, 2008, p. 135). Nessas hipóteses, portanto, a expressão "negará seguimento" equivale a "negará provimento".

A aplicação do dispositivo não é obrigatória. A possibilidade da sua utilização depende do nível de convencimento do relator, "quanto à matéria em exame, e à segurança, além da convicção, a respeito da baixa probabilidade de mudança de posicionamento pela jurisprudência ou pelos tribunais superiores" (CEI, 2009, p. 211). Assim, conclui-se que a aplicação do dispositivo é uma faculdade do juízo e não um dever.

\footnotetext{
17 Cabe frisar que, neste trabalho, não se está discutindo sobre a eficácia do art. 557, do CPC, mas apenas relacionando algumas das características presentes no dispositivo que se referem ao art. $518, \S 1^{\circ}$, do CPC.

18 Art. 557, caput, CPC: "O relator negará seguimento a recurso manifestamente inadmissível, improcedente, prejudicado ou em confronto com súmula ou com jurisprudência dominante do respectivo tribunal, do Supremo Tribunal Federal ou de Tribunal Superior."
} 
Além disso, a decisão do relator, quando relativa ao mérito, poderá substituir aquela proferida pelo juízo a quo. O mesmo ocorre com a decisão do relator que é impugnada pelo agravo interno e o colegiado a confirma (CEI, 2009, p. 211).

No que tange ao tema do item, a relação que se estabelece entre o art. 557 do CPC e a súmula impeditiva de recursos diz respeito, sobretudo, à competência que se atribui ao juízo de origem. De acordo com Rogério Licastro Torres (2010, p. 213), o art. 518, § 1º do CPC, permite ao juiz de primeiro grau de jurisdição o empreendimento de atividade judicante que é autorizada ao magistrado de segunda instância por força do art. 557 do CPC. O autor observa que se antecipa, em termos de procedimento, o trancamento liminar do recurso contrário a entendimento sumulado de tribunais excepcionais, que se faz no art. 557 do CPC (MELLO, 2010, p. 213).

Dessa forma, assim como ocorre com a utilização do art. 557 do CPC, a aplicação do art. 518, $\S 1^{\circ}$, do CPC é uma faculdade e não um dever do juízo a quo. O recebimento do recurso pelo juiz subordina-se ao seu nível de convencimento sobre a reduzida possibilidade de alteração da decisão proferida, da forma como ocorre no juízo ad quem, quando aplica o art. 557 do CPC. Diferentemente ocorreria, caso se entendesse a súmula impeditiva de recursos como requisito de admissibilidade. Nessa perspectiva, o juiz teria o dever, e não uma mera faculdade, de não receber o recurso de apelação. Isso porque esses requisitos de admissibilidade são matéria de ordem pública, tendo o juiz o dever analisálos, independentemente de provocação, e, na falta de um deles, não receber o recurso (CEI, 2009, p. 211).

Ademais, outro ponto que se pode ressaltar, quando a natureza da súmula impeditiva tiver ligação com o art. 557 do CPC, é que não há vinculação das decisões e das instâncias. A decisão proferida pelo juízo a quo é apenas um juízo de mérito provisório, uma vez que ela poderá ser alterada pelo tribunal, quer pelo prosseguimento normal da apelação, quer pela interposição de recurso.

Portanto, no caso da natureza da súmula impeditiva ser de alteração de competência do juiz a quo, e não de requisito de admissibilidade, à semelhança do que ocorre no art. 557 do CPC, os efeitos que considero mais importantes são os de que a aplicação do art. $518, \S 1^{\circ}$, do CPC seria uma faculdade do juízo e seria um juízo de mérito provisório do juiz de origem sobre o recurso de apelação interposto no processo (CEI, 2009, p. 215). 


\subsection{RECORRIBILIDADE}

Como já indicado, da decisão que aplica o art. 518, § $1^{\circ}$, do CPC cabe o recurso de agravo de instrumento. Isso se justifica por se tratar de decisão interlocutória, tendo como base o conceito dado pelo art. $162, \S 2^{\circ}$, do CPC, pois decide questão incidente. Cabe ressaltar que essa decisão não é sentença, pois não é ato que implique uma das hipóteses dos art. 267 e 269 do CPC, nem é despacho, por ter cunho decisório (CEI, 2009, p. 205).

Segundo Marinoni (2008, p. 533), a função do referido agravo de instrumento, com base no art. 522, do CPC, é evidenciar a não aplicabilidade do art. 518, § $1^{\circ}$, do CPC, seja argumentando que a súmula não é adequada à situação concreta, seja objetivando demonstrar que a súmula deve ser revista. Como esclarece o autor:

[...] o agravo que se limitar a trazer fundamentos comumente reiterados e já identificados pelos tribunais como insuficientes, sem seriamente argumentar acerca da necessidade da revisão ou a respeito da inaplicabilidade da súmula diante da situação concreta, deve ser considerado meramente protelatório e, assim, abrir oportunidade para a penalização do agravante com multa. (MARINONI, 2008, p. 534).

Assim, não há divergência na doutrina quanto à possibilidade de recurso e quanto a sua espécie. O que se questiona, geralmente, com relação à recorribilidade da decisão que aplicou a súmula impeditiva de recursos, é se o tribunal fica vinculado à decisão do agravo ou à decisão do juízo a quo e se é possível, já no agravo, dar provimento à apelação.

No que concerne à primeira questão, como já salientado em tópicos anteriores, entendo que não há vinculação do tribunal ad quem à decisão do juiz que trata da matéria referente ao recebimento da apelação. Segundo Marcelo Tuze Cei (2009, p. 206), considerando que essa decisão é um adiantamento do julgamento de mérito, se houver vinculação, ocorrerá um esvaziamento do recurso de apelação, devido ao julgamento do seu mérito em agravo, o que parece não estar de acordo com o sistema. Por outro lado, observa o referido autor, mesmo considerando a súmula impeditiva como requisito de admissibilidade, não há vinculação do tribunal a essa primeira decisão que cuida do recebimento do agravo. Isso porque o juízo ad quem deve reexaminar todos os requisitos de admissibilidade do recurso interposto, podendo modificar o entendimento do juízo de origem quanto à presença ou falta desses requisitos (CEI, 2009, p. 206).

Pelos mesmos motivos expostos acima, ainda com base no referido autor, não há a possibilidade do juízo ad quem reformar no agravo a sentença do juízo a quo. Acrescentam-se a essa conclusão dois outros motivos. O primeiro motivo é que não há 
previsão específica na lei para possibilidade de alteração da sentença em sede de agravo de instrumento. Já o segundo motivo pode ser visto sob duas perspectivas: se a súmula impeditiva for considerada requisito de admissibilidade, o recurso que ataca sua aplicação só poderá se pronunciar sobre o recebimento ou não recebimento da apelação; sendo a aplicação da súmula impeditiva uma espécie de antecipação do mérito pelo juízo de origem, mas suscetível de apreciação pelo tribunal, alterar a sentença no julgamento do recurso de agravo significaria prover o recurso e não há permissão para tal medida. Isso porque ocorreria violação ao princípio da singularidade, também chamado princípio da unirrecorribilidade ${ }^{19}$. Assim, seriam cabíveis, na hipótese, contra a sentença tanto o agravo de instrumento como a apelação (CEI, 2009, p. 206), sendo vedada essa possibilidade, conforme estabelece o referido princípio vigente no sistema do Código de Processo Civil brasileiro.

Com destaque, Hugo de Brito Machado (2006, p. 66-67 apud DONOSO, 2007, p. 39) sugere que o melhor seria a subida do agravo nos próprios autos principais, pois isso agilizaria o exame da apelação pelo tribunal no caso de provimento do agravo. Esse posicionamento, além de pragmático, considera que, se a apelação tem efeito suspensivo, não se justificaria a formação do instrumento, o que evita gasto de tempo e dinheiro (DONOSO, 2007, p. 39). Segundo o referido autor, nada impede que a apreciação de ambos os recursos fosse realizada simultaneamente. Se o recurso de agravo é cabível, melhor seria se o trabalho do tribunal fosse facilitado, permitindo-lhe julgar simultaneamente, se for o caso, ambos os recursos, sempre inspirado em valores de celeridade e de economia do processo.

\subsection{APLICABILIDADE EM OUTROS RECURSOS}

A súmula impeditiva de recursos é prevista no artigo que cuida do recebimento da apelação. Contudo, parte da doutrina entende que, nada obstante sua localização no Código de Processo Civil, ela pode ser aplicada para outros recursos, além do recurso de apelação.

Em sentido contrário, ressalta-se a opinião de Antonio Janyr Dall' Agnol Junior (2006, p. 185 apud DONOSO, 2007, p. 38), observando que o instituto criado pela Lei $\mathrm{n}^{\circ}$ 11.276/2006 é próprio e específico do recurso de apelação, não havendo a possibilidade de estendê-lo a outros recursos.

\footnotetext{
${ }^{19}$ Segundo esse princípio, ainda chamado de princípio da unicidade, “[...] para cada ato judicial recorrível há um único recurso previsto pelo ordenamento, sendo vedada a interposição simultânea ou cumulativa de mais outro visando à impugnação do mesmo ato judicial.” (NERY JUNIOR, 2004, p. 119).
} 
Entretanto, é razoável entender que o art. 518, $\S 1^{\circ}$, do CPC, assim como outros dispositivos pertencentes ao capítulo da apelação, possa ser extensível a outros recursos. Marcelo Tuze Cei (2009, p. 207) mostra que isso é o que ocorre, com a necessidade de fundamentação da apelação, prevista no art. 514 do CPC, e do efeito devolutivo ou proibição da reformatio in pejus, previsto no art. 515, do mesmo diploma, com a aplicação sistemática dos dispositivos para outros recursos, independentemente de previsão expressa para estes. Como exemplo dessa possibilidade, o autor faz referência ao recurso de embargos infringentes, no qual a fundamentação é considerada requisito de admissibilidade, sem que exista previsão a respeito (CEI, 2009, p. 207).

Ademais, é importante ressaltar que a aplicação da súmula impeditiva pode ser extensível a outros recursos, mas fica restrita àqueles que, assim como a apelação, são interpostos no juízo a quo e apreciados no órgão ad quem (DONOSO, 2007, 39). Como observa Cassio Scarpinella Bueno:

A aplicação do $\S 1^{\circ}$ do art. 518 a outros recursos que não o de apelação tem tudo
para ser em escala bem reduzida porque, pela própria dinâmica de seu
processamento, grande parte destes outros recursos já é interposta diretamente
perante os Tribunais e, desta forma, a atuação do relator, com base no art. 557 e no
seu respectivo $\S 1^{\circ}-$ A, tem tudo para alcançar o mesmo desiderato que o dispositivo
em referência. (BUENO, 2006, p. 41 ).

Nessa perspectiva, não há como proceder à aplicação da súmula impeditiva nos agravos, uma vez que interpostos diretamente à instância superior, quando na forma de instrumento, e porque, quando retido, serão sempre dependentes da apelação (CEI, 2009, p. 207). Além disso, como salientado por Cassio Scarpinella Bueno, com relação aos agravos, o art. 557 do CPC é um instrumento específico utilizado pelo relator que permite tanto o provimento quanto o não-provimento do recurso prima facie, além de não se prender, necessariamente, ao entendimento sumulado (DONOSO, 2007, p. 38).

Outra espécie de recurso que não permite o emprego da súmula impeditiva são os embargos de divergência. Isso porque, para sua admissibilidade, é preciso, justamente, que a divergência jurisprudencial não tenha sido superada. Do contrário, caso fosse aceita a aplicabilidade do instituto, haveria uma incongruência lógica do sistema processual. Segundo Marcelo Tuze Cei (2009, p. 207), "seria o mesmo que dizer que a súmula impeditiva, empregada em casos em que a divergência foi pacificada com a edição de súmula, é aplicável a recurso que cuida justamente dos casos em que há divergência de entendimentos". O autor alerta que, mesmo na hipótese em que determinada divergência jurisprudencial ressurja após edição de súmula, não há possibilidade do uso do referido instituto, sob pena de se admitir a inconsistência do sistema e a existência de antinomia (CEI, 2009, p. 208). 
No que tange ao recurso de embargos de declaração, também não se cogita da aplicação do art. 518, $\S 1^{\circ}$, do CPC. No caso, como o objetivo desse recurso é a eliminação de omissão, obscuridade ou contradição na decisão, não se cogita a possibilidade de reforma da decisão. Dessa forma, a eventual aplicação do instituto equivalerá a seu efetivo julgamento (DONOSO, 2007, p. 39).

Já com relação aos embargos infringentes. existem duas hipóteses de se pensar a aplicação da súmula impeditiva, dependentes da natureza desta. Entendendo o instituto como um adiantamento da aplicação do art. 557, do CPC, não há sentido o emprego da súmula impeditiva, porque possível, nessa fase, o uso do mesmo art. 557 do CPC, uma vez que o recurso já se encontra no juízo ad quem. Assim, é descabida a necessidade de outras antecipações. Por outro lado, considerada a súmula impeditiva um requisito de admissibilidade, não são encontrados impedimentos para sua aplicabilidade (CEI, 2009, p. 208).

Com relação aos recursos ordinários destinados aos tribunais excepcionais, o art. 540 dispõe que a esses recursos serão aplicados tantos os requisitos de admissibilidade, como os procedimentos pertinentes às apelações e aos agravos. No entanto, pouco do procedimento do agravo é comportável com o que pode ser atribuído ao recurso ordinário, ao contrário do que ocorre com o procedimento da apelação, que lhe é perfeitamente compatível. Dessa forma, compete ao juízo de origem obedecer às regras que competem à apelação, atribuídas, sobretudo, pelos artigos 514 e 518, sendo que, desse modo, pela natureza do recurso, a aplicação da súmula impeditiva é permitida (CEI, 2009, p. 208).

Nos recursos extraordinário e especial, a aplicabilidade da súmula impeditiva depende, novamente, da natureza que se dá ao referido instituto. Dependendo do entendimento que se tenha sobre a súmula impeditiva, se de juízo de admissibilidade ou mero adiantamento do art. 557 do CPC, entende-se pela possibilidade, ou não, de aplicação da referida súmula no âmbito de tais recursos.

Cabe ressaltar que os recursos extraordinário e especial são de índole excepcional, sendo voltados precipuamente a garantir a efetividade e a uniformidade de interpretação do direito federal e constitucional, não necessariamente o reexame de matéria decidida (WAMBIER; ALMEIDA; TALAMINI, 2006, p. 578).

Nesses recursos, o juízo de admissibilidade é exercido pelo juízo de origem, em caráter provisório, como ocorre com a apelação, e, logo em seguida, pelo tribunal ad quem. Assim, caso não admitido o recurso, cabe agravo de instrumento e, havendo juízo pela admissão deste, o recurso excepcional é reexaminado, agora, pelo órgão ad quem. 
Além disso, em razão da natureza de excepcionalidade, tais recursos possuem, além dos requisitos gerais de admissibilidade, requisitos específicos de admissibilidade, sendo que seus pressupostos são dados pela Constituição Federal e não pelo Código de Processo Civil, que se limita a reger seu procedimento (CEI, 2009, p. 209).

A partir de todo esse raciocínio, conclui-se que, considerando a súmula impeditiva como requisito de admissibilidade, entende-se que esse instituto não poderia ser aplicável aos recursos extraordinário e especial. Nessa hipótese, a sua aplicação usurparia a competência constitucional ao limitar a possibilidade de interposição dos recursos por questão relativa à matéria da decisão impugnada (CEI, 2009, p. 209). Ocorre que isso não se faz possível em sede dos recursos excepcionais, uma vez que os fundamentos e hipóteses de cabimento desses recursos estão previstos na Constituição Federal, não podendo norma ordinária estabelecer qualquer tipo de restrição (WAMBIER; ALMEIDA; TALAMINI, 2006, p. 578).

Contudo, se considerada a súmula impeditiva um adiantamento da função do relator do recurso extraordinário ou especial, a quem é permitido o julgamento monocrático, pelo não provimento do recurso em confronto com súmula do STF ou do $\mathrm{STJ}^{20}$, parece admissível a aplicabilidade do art. 518, $\S 1^{\circ}$, do CPC. Isso porque, nesse caso, não há infração constitucional, já que não há limitação ao julgamento do recurso ou criação de novo pressuposto não previsto na Constituição, mas apenas alteração quanto ao procedimento realizado, o que é lícito no ordenamento jurídico brasileiro (CEI, 2009, p. 209).

\footnotetext{
${ }^{20}$ Neste sentido, art. 557, do CPC, art. 21, § 1 $1^{\circ}$, do RISTF, e art. 34, XVIII, do RISTJ.
} 


\section{SÚMULA IMPEDITIVA DE RECURSOS: A QUESTÃO DO DUPLO GRAU DE JURISDIÇÃO E DO ACESSO À JUSTIÇA}

\subsection{RELEVÂNCIA DO ESTUDO DO TEMA}

A Constituição brasileira traz em seu bojo a garantia do estado democrático de direito, sobretudo, por meio dos princípios ali previstos. Partindo-se da premissa de que o direito processual tem suas bases estruturadas no direito constitucional, tem-se que os princípios constitucionais viabilizam a construção de um processo notadamente influenciado pela Constituição e pelo reconhecimento da necessidade de tratar seus institutos e interpretar sua lei em harmonia com o que ela estabelece.

Assim, a primeira análise que deve ser feita a toda norma infraconstitucional é se ela está em harmonia com os princípios constitucionais, especialmente diante da necessidade da leitura dos novos e dos tradicionais institutos processuais sob a vertente do modelo constitucional do processo.

Nessa perspectiva, na medida em que a súmula impeditiva de recursos permite ao julgador a quo obstar o prosseguimento do recurso, com fundamento em súmula do STJ ou do STF, limitando ao recorrente o direito ao recurso de apelação, objetiva-se saber se o referido instituto viola o princípio constitucional do duplo grau de jurisdição e, consequentemente, o direito de acesso à justiça daquele que busca a tutela jurisdicional. É de se entender pertinente e atual o estudo do tema, uma vez que envolve a controvérsia acerca da constitucionalidade ou não da chamada súmula impeditiva de recursos introduzida pelo artigo 518, $\S 1^{\circ}$, do Código de Processo Civil, tendo em vista o princípio constitucional do duplo grau de jurisdição.

\subsection{A SÚMULA IMPEDITIVA DE RECURSOS E O PRINCÍPIO DO DUPLO GRAU DE JURISDIÇÃO}

Como verificado, o princípio do duplo grau de jurisdição possibilita que toda decisão judicial seja submetida à nova revisão, normalmente por órgão de jurisdição diverso daquele que proferiu a primeira decisão. A defesa do duplo grau como princípio 
constitucional pauta-se, sobretudo, no fundamento de que há uma estrutura judicial e processual que favorecem o duplo exame das decisões, podendo, entretanto, o legislador infraconstitucional limitar o direito do jurisdicionado ao recurso.

Como salientado neste trabalho, apesar de o duplo grau ser considerado um princípio constitucional, a própria Constituição limita o seu âmbito de abrangência ao apresentar hipóteses em que é excepcional a recorribilidade dos julgados. Além disso, é um princípio que deve ter aplicação moderada pelos ordenamentos jurídicos, pois o sistema constitucional brasileiro prevê uma variada gama de outros princípios que devem ser analisados em determinada circunstância, ora prevalecendo uns, ora outros.

Nessa perspectiva, entende-se que o duplo grau de jurisdição existe apenas como um princípio, presente de forma implícita, mas não como uma garantia constitucional.

Dessa forma, fica evidente que a não obrigatoriedade do referido princípio abre ao legislador infraconstitucional a possibilidade de restringir o cabimento dos recursos, com o objeto de trazer efetividade ao processo, não devendo tais restrições serem consideradas inconstitucionais (NERY JUNIOR, 2004, p. 42). O princípio do duplo grau de jurisdição serviria apenas como um indicador ao legislador, que deverá preservá-lo. Isso porque, concomitante à discussão sobre a sua existência e preservação no sistema processual, em plano de relativa importância apresenta-se a questão sobre a celeridade. Evidentemente que, na mesma medida em que se prestigia e privilegia-se o duplo grau de jurisdição, a celeridade é atingida negativamente (CEI, 2009, p. 219).

Por isso é que parte da doutrina, em oposição ao duplo grau, chega a entender que a sua aplicação indiscriminada viola regramentos constitucionais e também distancia o julgamento da causa da norma e dos fatos concernentes ao caso concreto. Como observa Marinoni (1999, p. 207), o direito ao duplo grau de jurisdição deve ser analisado à luz do art. $5^{\circ}$, inciso XXXV, da Constituição Federal, que exalta o princípio do acesso à justiça, se extraindo desse dispositivo o direito à tempestividade da tutela.

Como foi visto ao longo do segundo capítulo deste trabalho, nos dias atuais, a razoável duração do processo é um aspecto essencial para se proporcionar uma efetiva tutela dos direitos. Não pode o jurisdicionado ser vítima do uso abusivo, por uma da partes de um processo, dos mais diversos meios processuais para protelar a prestação jurisdicional e perpetuar o procedimento. Nesse contexto, foi que a Constituição Federal, no seu art. $5^{\circ}$, inciso LXXVIII, elegeu tanto a necessidade da duração razoável do processo, quanto a celeridade da sua tramitação no rol dos direitos fundamentais, tendo como objetivo o pleno acesso à justiça, por meio, sobretudo, da efetividade da tutela jurisdicional. 
Assim, é a partir desse quadro que a constitucionalidade da súmula impeditiva de recursos, sob o viés da contrariedade ao duplo de jurisdição, deve ser avaliada. Deve-se entender, por hipótese, que ocorre um conflito de princípios constitucionais, havendo a necessidade de se aplicar regra própria e adequada para o cotejo desses princípios. Para tal cotejo, será utilizado aqui o princípio da proporcionalidade.

Segundo Luís Roberto Barroso (2009, p. 375), o princípio da proporcionalidade é um instrumento complexo de interpretação que se desdobra em três fases para que se efetue a interpretação da constitucionalidade de uma norma, ou de atos do poder público, quando sua aplicação causar o conflito entre princípios constitucionais. A três fases de exame são: (i) o exame da adequação entre o fim pretendido e o meio utilizado; (ii) o exame da necessidade, se não há outro meio menos gravoso para chegar ao mesmo resultado; (iii) o exame da proporcionalidade em sentido estrito que é a ponderação entre o que se ganha e o que se perde com a adoção da medida.

No que diz respeito à súmula impeditiva de recursos, primeiramente, deve-se observar se há adequação entre o referido instituto e o seu fim pretendido, que no caso é o aumento da celeridade na tramitação dos processos.

Ao interromper a possibilidade de seguimento do processo, não há muita dificuldade em se chegar à conclusão de que haveria um aumento de celeridade, pelo menos com relação às causas que estejam em consonância com o entendimento sumulado. Em relação ao andar geral dos processos, também parece possível algum aumento da celeridade em seu julgamento, pois, em teoria, uma quantidade menor de trabalho é realizada mais rapidamente que uma maior, ou seja, privilegia-se a consecução de um resultado com o mínimo de gasto de energia e tempo ${ }^{21}$ (CEI, 2009, p. 221).

No que se refere à necessidade da súmula impeditiva, devido à falta de outro meio menos gravoso para a consecução de um determinado fim, no caso o aumento da celeridade dos julgamentos, uma parcela da doutrina entende que esse instituto pode ser menos gravoso, em comparação a outros sistemas que são utilizados para acelerar o trâmite das causas fundadas em matéria sumulada. Para esses estudiosos, a súmula impeditiva de recursos evita o denominado "risco de engessamento do precedente" (ARAÚJO, 2006, p. 91), pois pode o magistrado receber o recurso e determinar seu processamento mesmo havendo determinada

\footnotetext{
21 Inclusive, Barbosa Moreira estabelece esse objetivo, entre as cinco características, que o processo deve ser ou conter para ser efetivo. Essas características são: (a) que tenha instrumentos de tutela adequados a todos os direitos do ordenamento; (b) deve ser utilizável na prática por qualquer titular de um direito; (c) deve trazer informações suficientes ao convencimento do julgador quanto à matéria de fato; (d) deve assegurar o gozo do bem da vida; (e) deve atingir o resultado a que se propõe com o mínimo gasto de tempo e energia (MOREIRA, 1995, p. 168 apud CEI, 2009, p. 226).
} 
súmula que, em tese, impeça sua subida. Basta que o magistrado demonstre seu convencimento, no sentido de que o apelo merece ser remetido ao tribunal ad quem.

O instituto processual não traz risco ao poder de criação, de investigação e de independência do magistrado de primeira instância. Assim, observa José Henrique Mouta Araújo, ao comparar a súmula impeditiva de recursos com o paradigma da súmula vinculante, no que se refere à questão do poder de criação do magistrado:

Realmente, se em decorrência da súmula vinculante há risco de engessamento do precedente e choque em relação ao poder de criação do juiz, na súmula impeditiva de recurso protege-se a atuação do magistrado, sendo possível a utilização do instituto em caso de manejo de recurso contra a decisão fundada exatamente no precedente sumulado. (ARAÚJO, 2006, p. 91).

Todavia, a meu ver, a análise da questão da necessidade da súmula impeditiva, devido à falta de outro meio menos gravoso para a consecução do aumento da celeridade dos julgamentos, é bem mais complexa. Como observa Marcelo Tuze Cei (2009, p. 222), é possível imaginar diversos outros métodos, como de fato tem ocorrido, constantemente, gerando todo tipo de reforma no processo civil que viabiliza o mesmo fim $^{22}$.

No entanto, segundo o autor supracitado, se for restringir o pensamento apenas no sentido de acelerar o trâmite das causas fundadas em matéria sumulada, apesar de existir a possibilidade de serem criados outros sistemas, alguns que partem até de ideias semelhantes, como, a título de exemplo, é o caso da súmula vinculante, não é adequado dizer que há outro meio menos gravoso. Isso porque não há, ainda, a percepção de que se esteja próximo de encontrar outros meios menos gravosos que vise à celeridade processual e, mesmo que haja, não são necessariamente incompatíveis ou atingem a finalidade por si só (CEI, 2009, p. 222).

$\mathrm{Na}$ verdade, não há, particularmente no caso brasileiro, dados abrangentes e confiáveis que possam aferir que um determinado instrumento processual proporcione ao processo uma duração razoável ${ }^{23}$. Além disso, há fatores residentes na realidade política, social, econômica e cultural, na qual o processo se destina a servir, que fazem compreender que a solução para o problema da demora dos processos não é única e não se esgota apenas pela via legislativa (RODRIGUES, 2008, p. 324). Como observa Walter dos Santos Rodrigues,

\footnotetext{
${ }^{22}$ Verifica-se o mesmo propósito, por exemplo, nas Leis n ${ }^{\mathrm{o}}$ 11.277/06 e 11.382/06 - que, respectivamente, dá poder ao juiz de indeferir petição inicial que objetive decisão que já foi proferida em caso idêntico e estabelece a fase de cumprimento da sentença no processo de conhecimento - cuja intenção do legislador foi concretizar a celeridade e economia processual, com vistas a uma tutela jurisdicional em tese mais efetiva.

${ }^{23}$ Como observa Barbosa Moreira, em uma sensata anotação feita em estudo sobre a súmula vinculante, que pode ser aplicável no presente estudo: "Faltam-nos [...] dados estatísticos abrangentes e confiáveis sobre a duração de processos. Em regra, os juízos que se emitem não têm outra base senão as impressões colhidas, em hipótese otimística, na experiência pessoal de cada opinante - experiência, ocioso frisar, extremamente variável de caso a caso, além de sujeita a mil distorções impostas pelo filtro da subjetividade.” (MOREIRA, 2006, p. 190-191 apud CEI, 2009, p. 222).
} 
[...] é possível reparar que há pluralidade de causas para a demora da Justiça. Há algumas questões de ordem técnica-jurídica, outras de ordem física, material e financeira. Há algumas questões de ordem estrutural e institucional, outras de ordem funcional, relativas ao recrutamento, seleção, formação, atuação e desempenho de seu corpo de profissionais. Há ainda questões de ordem política que envolvem a variedade de opções político-administrativas viáveis e as disputas entre interesses corporativos e individuais. Sem falar das questões de ordem cultural e social, que dizem respeito à mentalidade, aos valores e ao papel desempenhado pelos atores sociais envolvidos. (RODRIGUES, 2008, 324).

Nesse sentido, cabe frisar que as reformas processuais contribuem para busca do objetivo de tornar a tutela jurisdicional mais célere, mas não são suficientes por si só, pois existem aspectos alheios à dogmática processual que precisam, também, ser considerados.

Já com relação ao exame da proporcionalidade em sentido estrito, é preciso avaliar se o que se ganha com a adoção da súmula impeditiva faz compensar o que se perde. É claro que, no âmbito deste trabalho, a análise desse item ficará restrita à colisão com o princípio do duplo grau de jurisdição.

No caso, para que seja feita uma análise coerente, é necessário que se tenha em mente os fins primordiais que, comumente, fundamentam o princípio do duplo grau de jurisdição, quais sejam, a possibilidade de se permitir decisões de maior qualidade e o controle da atividade do juiz, uma vez que os órgãos hierarquicamente superiores "controlam", de certo modo, as decisões dos inferiores. De acordo com a doutrina, esses fins são vinculados à garantia de uma boa solução (CEI, 2009, p. 222).

Nesse momento, torna-se importante saber a natureza dada à súmula impeditiva de recursos. Como visto no capítulo anterior, dependendo da natureza que se imprima ao instituto, os efeitos decorrentes dessa natureza tem intensidades diferentes, inclusive, tendo reflexo direto no princípio do duplo grau de jurisdição.

Cabe lembrar que, quando a súmula impeditiva é vista como um requisito de admissibilidade, tem-se como obrigatória sua aplicação. Dessa forma, mesmo tratando-se de matéria em que haja controvérsia, a discussão não é viabilizada. Por outro lado, na outra interpretação, da natureza da súmula impeditiva como antecipação do mérito, não há o mesmo problema. Não sendo o recebimento do recurso obrigatório, que fica condicionado ao grau de convencimento do juízo sobre a pequena possibilidade de alteração da decisão proferida, mantém-se aberta a possibilidade de reapreciação da decisão nas hipóteses em que houver controvérsia da matéria em discussão.

Como requisito de admissibilidade, poder-se-ia entender que a obrigatoriedade de aplicação da súmula impeditiva de recursos opõe-se à possibilidade de um segundo reexame do mérito ou - da forma posta pela maioria da doutrina - a uma decisão de melhor 
qualidade. Isso porque o juízo de admissibilidade é matéria de ordem pública. O juiz ou o tribunal devem examinar se a sentença está em conformidade com súmula do STJ ou do STF, e mesmo que tenham entendimento diverso ao da súmula, devem evitar decisões inúteis e o prosseguimento desnecessário do processo.

Assim, em razão dessa obrigatoriedade, poder-se-ia pensar que a aplicação da súmula impeditiva torna-se uma afronta ao princípio do duplo grau de jurisdição, inclusive, para aquelas hipóteses em que não há consenso em torno de interpretação acobertada por súmula, desde sua formulação ou então superveniente em razão da evolução do direito.

Contudo, na hipótese referida acima, não se compreende que há violação ao duplo grau de jurisdição, uma vez que esse princípio não é uma garantia constitucional absoluta, havendo a possibilidade de restrições a sua aplicação. Além disso, o fim celeridade é alcançado em seu grau máximo, porque há a obrigatoriedade de não conhecimento da apelação, consequentemente o encerramento precoce do feito e a diminuição da carga de trabalho imposta ao judiciário (CEI, 2009, p. 216).

Deve-se salientar que é garantia constitucional a duração razoável do processo, expressa no art. $5^{\circ}$, inciso LXXVIII, da Constituição Federal. Dessa forma, a demora do processo, antes considerada como aspecto acidental dado à complexidade da ciência processual, nos dias de hoje, não pode mais ser negligenciada. Isso porque toma-se consciência de que o processo deve atender aos anseios do direito material e, sendo para este instrumento de sua efetivação, não há mais como deixar de atentar contrariamente a sua demora injustificada. Como ressalta Cruz e Tucci, citando Rafael Bielsa e Eduardo Graña:

$\mathrm{O}$ resultado de um processo não apenas deve outorgar uma satisfação jurídica às partes, como, também, para que essa resposta seja a mais plena possível, a decisão final deve ser pronunciada em um lapso de tempo compatível com a natureza do objeto litigioso, visto que - caso contrário - se tornaria utópica a tutela jurisdicional de qualquer direito. (CRUZ E TUCCI, 1999, p. 236).

Portanto, por ser considerada hipótese de restrição ao duplo grau, não significa que a súmula impeditiva está restringindo o acesso à atividade jurisdicional, tendo em vista que está sendo privilegiada a celeridade, outro princípio constitucional.

Por outro lado, na outra interpretação, da natureza da súmula impeditiva como uma antecipação de mérito, já se abre outra perspectiva, não encontrando tantas incompatibilidades com o vigente sistema processual. Nesse entendimento, a celeridade não é tão privilegiada, em razão da não obrigatoriedade de aplicação do referido instituto pelo juízo a quo, significando que em menor número de ações haveria extinção precoce do processo, mas a possibilidade de haver o reexame da decisão é facilitada (CEI, 2009, 216). Aqui, assim 
como ocorre com a utilização do art. 557 do CPC, a aplicação do art. 518, § $1^{\circ}$, do CPC, é uma faculdade, e não um dever do juízo a quo, sendo que o recebimento do recurso pelo juiz subordina-se ao seu nível de convencimento sobre a reduzida possibilidade de alteração da decisão proferida em conformidade com súmula do Superior Tribunal de Justiça ou do Supremo Tribunal Federal.

Assim, nessa interpretação, também, não se observa ofensa ao princípio do duplo grau de jurisdição, pois é mantida a possibilidade de reapreciação pelo órgão ad quem, visando à prestação da tutela jurisdicional àquele que alega ter razão.

Ademais, em outra perspectiva em torno da aplicação da súmula impeditiva, relacionada, ainda, com a interpretação que a considera uma antecipação do juízo de mérito, poderia se pensar que esse instituto representa a admissão pelo sistema processual da possibilidade do próprio juízo a quo suprimir o direito ao reexame da sua decisão pela instância superior e proceder ao julgamento do mérito do recurso. Isso violaria o sugerido modelo constitucional do processo civil, proporcionando a inconstitucionalidade do instituto processual, porque a supressão de instância é sinônimo de usurpação de competência, com consequencias em princípios como, por exemplo, o do juiz natural (DONOSO, 2007, p. 37).

Todavia, não é cabível esse entendimento, pois a regra que instituiu a súmula impeditiva de recursos é uma mitigação ao princípio do duplo grau de jurisdição, que não é absoluto no ordenamento jurídico brasileiro, como também não o é qualquer outro princípio constitucional (DONOSO, 2007, p. 37). De forma sensata, acresce Marinoni:

Como se sabe, o processo é fenômeno historicamente determinado; não é possível atribuir a ele características imutáveis e universalmente válidas. O duplo grau, não é garantido constitucionalmente, não pode mais ser visto como um princípio fundamental de justiça, já que não é racional - quando se está consciente da necessidade de garantir ao autor uma maior tempestividade da tutela jurisdicional admitir a sua presença em todas as causas [...] (MARINONI, 1999, p. 232).

Válido ressaltar, ainda, que, com a aplicação do art. 518, § $1^{\circ}$, do CPC, o controle das decisões proferidas pelo juízo a quo não deixa de existir plenamente. Indiferentemente da natureza da súmula impeditiva, de juízo de admissibilidade ou de mérito, há a possibilidade de interposição de agravo de instrumento contra a decisão que não recebe o recurso de apelação interposto, com a análise da conformação da sentença com o teor da súmula e com o conteúdo fático dos autos (CEI, 2009, p. 223). Dessa maneira, embora o instituto seja considerado uma mitigação ao princípio do duplo grau, um dos fins apontados ao princípio não deixa de ser atendido, consistente no controle das decisões judiciais.

Portanto, a súmula impeditiva de recursos não viola o princípio do duplo grau de jurisdição, tanto para os que aceitam o instituto processual como requisito de 
admissibilidade como para os que a entendem apenas como juízo de mérito. Frisa-se que esse instituto constitui mais um instrumento que representa uma opção de política legislativa, que preferiu, sob critérios de proporcionalidade, privilegiar valores como a celeridade, tendo em vista o direito consagrado pela Constituição Federal, no seu art. $5^{\circ}$, inciso XXXV, que impõe o dever ao legislador processual de construir mecanismos aptos que tutelem de forma efetiva, adequada e tempestiva os direitos daqueles que buscam o aparato estatal. 


\section{CONSIDERAÇÕES SOBRE A SÚMULA IMPEDITIVA DE RECURSOS E O NOVO CÓDIGO DE PROCESSO CIVIL}

Quando se verifica a Exposição de Motivos do vigente Código de Processo Civil de 1973, observa-se que ele buscou, na época em que foi instituído, proporcionar ao processo civil um sistema mais célere e racional, em substituição ao Código de 1939.

Não obstante o avanço, a celeridade processual não foi efetivamente alcançada. Constatou-se, entre outros problemas, que muitas das ferramentas à disposição do cidadão não eram adequadas para tutelar interesses de forma efetiva. Isto fez com que muitos processualistas brasileiros começassem, sobretudo na última década do século XX, a dedicarse com mais afinco à reestruturação do processo civil, uma vez que, especificamente no caso brasileiro, havia um clamor social contra a morosidade da justiça (MESQUITA, 2008, p. 165). Como mostra Cruz e Tucci,

Relegando a um plano secundário as construções de cunho teórico, que tanta relevância ostentaram até há bem pouco tempo, os processualistas passaram a preocupar-se com um valor fundamental, ínsito à tutela dos direitos, qual seja, a imprescindibilidade da efetividade do processo, enquanto instrumento de realização de justiça (CRUZ E TUCCI, 1999, p. 234).

Assim, durante todo esse tempo, as comissões de reforma processual vêm repensando institutos vigentes, tentando superar entraves reais e concretos à tempestividade da prestação jurisdicional, buscando proporcionar, com isso, o efetivo acesso à justiça e a duração razoável do processo, consoante previsão do art. $5^{\circ}$, inciso LXVIII, da Constituição Federal (ARAÚJO, 2006, p. 86).

Válido ressaltar que a inserção da garantia do processo sem dilações indevidas ou com duração razoável, inserida pela Emenda Constitucional no 45, desencadeou uma variada gama de discussões e uma generalizada preocupação na comunidade jurídica e na própria sociedade a respeito das causas da morosidade processual e as possíveis soluções para a sua amenização. Dessa forma, como consequência, as várias reformas perpetradas ao Código de Processo Civil, além de proporcionar inovações perceptíveis ao sistema processual vigente, refletiram novas perspectivas e concepções adotadas pelo processo civil, não reconhecidas, muitas vezes, pela dogmática tradicional.

No caso, a súmula impeditiva de recursos, objeto do presente estudo, insere-se nesse quadro de mudanças. Destaca-se que o referido instituto - na linha de outras tantas alterações no sistema processual, em especial como consequência da Emenda Constitucional 45, que, dentre vários aspectos, concedeu poder ao Supremo Tribunal Federal de estabelecer 
súmulas de efeito vinculante, inclusive a todas as esferas da administração pública - é mais um dos mecanismos de seletividade judicial, criado no âmbito das reformas processuais civis, que adota a técnica da vinculação a precedentes como medida.

Segundo Nério de Andrade Brida (2006), a possibilidade de integração do instituto da súmula impeditiva de recursos ao sistema processual teve espelho no entendimento de que a súmula representa um posicionamento unitário e harmônico da jurisprudência do tribunal sobre um determinado aspecto do direito. Assim, observa, tornouse óbvio considerar que as súmulas do Supremo Tribunal Federal e do Superior Tribunal de Justiça proporcionam, em tese, a mais correta aplicação do direito, sendo coerente dotá-las de força suficiente para impedir que novos recursos sobre o mesmo tema cheguem aos tribunais, com provável resultado idêntico dos casos anteriores.

Não é de hoje que o legislador brasileiro vem no sentido de fortalecer os precedentes, levando a uma nova perspectiva no tocante ao tratamento da jurisprudência, inclusive, influenciando a sistemática recursal. De forma gradual, o legislador veio inserindo institutos processuais cada vez mais tendentes a reconhecer a força dos precedentes, em especial a produção dos tribunais superiores. Exemplo claro dessa medida foi o estabelecimento da possibilidade de negar seguimento ou provimento a recurso, como ocorre no art. 557, caput e $\S 1^{\circ}$, à luz da jurisprudência dita predominante dos tribunais superiores. Este dispositivo chega até a penalizar com multa quem recorra contra entendimento em consonância com a jurisprudência pacificada dos tribunais superiores, como se observa da leitura do seu parágrafo segundo (PARENTE, 2007, p. 168).

Nessa perspectiva, se o relator do recurso de apelação pode, por decisão pessoal, negar o seguimento ao recurso ou, ainda, reformá-lo quando presentes os requisitos necessários para tanto, não seria justificável não deter poder semelhante o juiz que proferiu a sentença em primeiro grau, haja vista o dever do legislador de buscar coerência ao sistema processual.

Assim, a partir desse entendimento, a súmula impeditiva no recurso de apelação foi adotada como um mecanismo de restrição de acesso aos tribunais ordinários, com o objetivo de proporcionar razoável duração ao processo e dar celeridade a sua tramitação, tendo em vista o disposto no art. $5^{\circ}$, inciso LXXVIII, da Constituição Federal.

Além disso, observa-se que, a partir do estudo da súmula impeditiva, o caminho construído através das reformas processuais, ocorridas durante esses últimos anos, mostra a adoção pelo legislador processual de mecanismos de seletividade judicial, com clara intenção 
de evitar-se ao máximo recurso infundado e em contradição às decisões dos tribunais superiores, inclusive, ocorrendo a ampliação dos poderes dos magistrados de primeiro grau.

O novo Código de Processo Civil, o que se pretende adotar, em breve, também nasce em um contexto de abertura para novas perspectivas e concepções relativas ao processo civil, sendo, inclusive, um reflexo dessas mudanças. Percebe-se, através da leitura da sua exposição de motivos $^{24}$, que se buscou construir um procedimento que tenha potencial possibilidade de tutelar de forma efetiva e tempestiva a prestação jurisdicional, sem o abandono total da técnica processual anterior.

Nesse novo código, a súmula impeditiva de recursos, objeto do presente trabalho, será abolida. Frisa-se, contudo, que o cerne desta, que é técnica da vinculação a precedentes, configura-se como a sua característica mais marcante. Há uma clara intenção de dificultar a reforma de decisão fundada em súmula, apesar de ser mantida ao juiz de primeiro grau a liberdade de decidir, mesmo que contrariamente à súmula. Assim, apesar da abolição da súmula impeditiva, a técnica da vinculação empregada pelo instituto continua tendo aplicação no novo diploma processual.

Cabe ressaltar que o ideário do novo CPC é a celeridade. Procura-se racionalizar o processo civil extinguindo ou reformulando procedimentos. O objetivo é dar maior efetividade ao processo, tornando-o um instrumento apto a satisfazer aquele que busca o judiciário para obter determinada prestação.

Nesse passo, tendo o novo CPC como ideário a celeridade, observa-se que os questionamentos, geralmente realizados em torno da súmula impeditiva de recurso, como por exemplo, se houve a supressão de etapa recursal, violando assim o duplo grau; se houve ofensa a determinada ideia de justiça, de processo; entre outras questões, acabam esvaziandose, já que a celeridade torna-se um ponto crucial.

Além disso, passa-se a entender que o formalismo excessivo, quase como um fetichismo à forma, retira do processo sua finalidade, devendo ser procurados os fins em contraposição à forma ou às concepções imutáveis. Isso mostra que o novo CPC, ao escolher, por exemplo, pela adoção de mecanismo de seletividade judicial, busca restringir os meios recursais, na tentativa de atingir, em um menor espaço de tempo, a certeza jurídica e a efetividade do processo. Há uma mudança de rota, com o código ora proposto, numa tentativa que objetiva conciliar o direito à tempestividade da tutela jurisdicional com a necessidade do ordenamento processual atender, do modo mais completo e eficiente possível, ao pleito

\footnotetext{
${ }^{24}$ Disponível em:< http://www.senado.gov.br/senado/novocpc/pdf/Anteprojeto.pdf $>$. Acesso em: 10 nov. 2011.
} 
daquele que exerce o seu direito à jurisdição, bem como daquele que resiste, apresentando defesa (CRUZ E TUCCI, 1999, p. 235).

Nessa perspectiva, o referido Código reflete um novo momento. É sabido que, apesar de o direito processual civil ter seu caráter formal, dotado de cunho técnico, ele tem o seu tecido interno formado pela confluência de ideias, projetos sociais, interesses econômicos, políticos e estratégias de poder reinantes em determinada sociedade, em consonância com um determinado tempo e espaço social (OLIVEIRA, 1999, p. 132). Como observa Carlos Alberto Alvaro de Oliveira:

A estrutura mesma do processo civil não é moldada pela simples adaptação técnica
do instrumento processual a um objetivo determinado, mas especialmente por
escolhas de natureza política, em busca dos meios mais adequados e eficientes para
a realização dos valores que dominam o meio social, estes sim estruturando a vida
jurídica de cada povo, de cada nação, e cada Estado. (OLIVEIRA, 1999, p. 132).

A súmula impeditiva de recursos, entre outras modificações no âmbito recursal, de busca de celeridade, de efetividade, a meu ver, representou um momento de transição que desembocou para formação do novo Código de Processo Civil, com intento de trazer celeridade ao procedimento judicial. Quanto aos possíveis questionamentos com relação a essa busca incessante pela celeridade, estes ficam para trás, uma vez que se procura não se ater a um discurso superficial, fundamentado na forma, mas sim, profundamente voltado para as finalidades do processo, ou seja, para uma análise teleológica do processo.

Frisa-se, todavia, a necessidade de se ter em mente que a efetividade do processo não se traduz somente em celeridade, mas deve estar vinculada a um valor transcendente que é o valor da justiça. Também, que a celeridade não é valor absoluto. Perigoso seria se assim fosse considerada e buscada a qualquer custa. Finalmente, deve ser entendido que não é a segurança valor absoluto, pois oferecer inúmeras possibilidades de impugnação, mesmo que se considere mínima a possibilidade de êxito, não é algo razoável. Deve haver equilíbrio (CEI, 2009, p.226).

Daí revela-se a relação entre celeridade e segurança. Para isso, é de suma importância que o processo civil possua mecanismos aptos a desempenhar de maneira efetiva a sua função, mas que permita uma racional distribuição do tempo do processo. Como afirma Cruz e Tucci (1999, p. 237), obtendo-se o equilíbrio entre segurança e celeridade é que emergirão as melhores condições para garantir a justiça no caso concreto, sem que, assim, ocorra a diminuição no grau de efetividade da tutela jurisdicional. Portanto, é nesse sentido que deve se pautar o novo Código de Processo Civil. 


\section{CONSIDERAÇÕES FINAIS}

De tudo que foi exposto, pode-se concluir que o art. 518, § $1^{\circ}$, do $\mathrm{CPC}$, denominado pela doutrina de súmula impeditiva de recursos, não viola o princípio do duplo grau de jurisdição, apesar de ser considerado um mecanismo que limita o direito ao recurso de apelação, criado pela Lei n ${ }^{\circ} 11.276 / 2006$.

Como instrumento de controle de decisões, o duplo grau de jurisdição não pode ser confundido como medida de controle da própria atividade do juiz, até porque este não tem subordinação hierárquica no desempenho de suas funções, mas, idealmente, um instrumento que possibilite ao vencido o direito à revisão da decisão que lhe foi contrária.

Por outro lado, apesar dessa incumbência instituída para o princípio do duplo grau, no sentido de ser um elemento de segurança jurídica e a ponderação dos julgamentos, não é coerente dizer, por exemplo, que o juiz mais experiente, que não teve qualquer contato com as partes e com prova, é necessariamente aquele que está mais bem preparado para decidir a causa. Essa é uma mera percepção. Um fundamento falho, de cunho, extremamente, subjetivo.

Do ponto de vista do ordenamento jurídico brasileiro, apesar de o duplo grau de jurisdição ser considerado um princípio constitucional, ele não está garantido de forma absoluta. A própria Constituição limita o seu âmbito de abrangência ao apresentar hipóteses em que é excepcional a recorribilidade dos julgados. Assim, pode o legislador infraconstitucional limitar o direito ao recurso.

Além disso, esse princípio é ponderado com outros valores (como, por exemplo, o da celeridade) que devem ser avaliados, tendo em vista a gama de princípios que devem ser considerados em um determinado sistema processual, não sendo viável a aplicação indiscriminada de qualquer desses princípios.

Como pôde ser demonstrado neste trabalho, a súmula impeditiva de recursos foi adotada em um novo contexto de acesso à justiça, numa realidade em que o acesso à tutela judicial efetua-se quando há uma efetiva prestação jurisdicional por parte do poder judiciário, em um espaço de tempo compatível com a natureza do objeto litigioso. Concebido como um mecanismo de seletividade judicial, que busca trazer benefícios à celeridade do processo e a sua efetividade, esse instituto reflete a busca por instrumentos processuais que racionalizem o sistema processual, com objetivo de que este desempenhe o papel que lhe toca no 
ordenamento jurídico, em consonância com a garantia prevista no artigo $5^{\circ}$, inciso LXXVII, da Constituição Federal.

Assim, como verificado, a súmula impeditiva é uma opção de política legislativa, que busca a celeridade da prestação jurisdicional. E, infelizmente, não há dados, pelo menos estatísticos, confiáveis e concretos, que possam constatar que o referido instrumento esteja, realmente, proporcionando tal celeridade.

Dessa forma, ainda que o instituto reduza o aspecto cognitivo da matéria a ser avaliada, não é claro se incidentes que possam ser criados, como por exemplo, o agravo da decisão que não recebe a apelação, torna o processo ainda mais lento. Todavia, apesar dessa deficiência de percepção, não é razoável entender que o cidadão precise percorrer inúmeras etapas de impugnação, com objetivo de alcançar, em tese, a verdade sobre os fatos, mesmo se constatando que o mérito do recurso não terá chance de ser reconhecido na instância superior.

Também é preciso frisar que modificações da legislação processual, quando motivadas pela busca do aperfeiçoamento de determinada estrutura vigente, contribuem, positivamente, para o objetivo de tornar a tutela jurisdicional mais célere e efetiva. Apesar de que pode ser observado que essas modificações não são suficientes por si só, pois existem fatores residentes na realidade política, social, econômica e cultural aos quais o processo se destina a servir, que fazem compreender que a solução para o problema da demora dos processos judiciais não se limita apenas a aspectos legislativos.

Além disso, constata-se que os conhecidos mecanismos alternativos de solução de conflitos, como, por exemplo, a conciliação e a mediação, precisam ser valorizados. Esses métodos, em alguns casos, mostram-se capazes de produzir resultados melhores que os da jurisdição estatal.

De fato, as vias de acesso ao judiciário, sobretudo aos tribunais superiores, estão cada vez mais congestionadas com um volume de demandas muito superior a sua real capacidade. Dessa forma, as soluções alternativas, para se evitar o acesso ao judiciário, desde que se mostrem eficazes, desempenham um papel de suma importância.

Cabe ressaltar, finalmente, que a súmula impeditiva de recursos será abolida no novo CPC. Todavia, apesar da sua supressão, a técnica da vinculação a precedentes, empregada pelo instituto, é um dos aspectos principais que caracterizam esse novo diploma processual. Isso mostra que a celeridade processual tornou-se, efetivamente, um novo paradigma processual, tendo em vista a garantia da razoável duração do processo, que é um desdobramento natural do princípio constitucional do acesso à justiça, disposto no artigo $5^{\circ}$, inciso XXXV, da Constituição Federal. 
E a partir dessa nova perspectiva, caso se constate que essa busca por celeridade não esteja anulando outros valores que, em princípio, lhe são opostos, a Constituição é cumprida e respeitada. Assim, não há que se falar em qualquer espécie de violação, principalmente, quando esse ideário contribui para efetuar um valor fundamental, ínsito à tutela dos direitos, qual seja o da efetividade do processo, enquanto instrumento de realização da justiça. 


\section{REFERÊNCIAS}

ALMEIDA, Flávio Renato Correia de; TALAMINI, Eduardo; WAMBIER, Luiz Rodrigues (Coord.). Curso avançado de processo civil. 8. ed. São Paulo: RT, v.1, 2006.

ARAÚJO, José Henrique Mouta. Súmula impeditiva de recursos: uma visão sobre o atual quadro processual brasileiro. Revista dialética de direito processual. São Paulo, n. 39, p. 8692, 2006.

BARROSO, Luís Roberto. Interpretação e aplicação da Constituição: fundamentos de uma dogmática constitucional transformadora. 7. ed. São Paulo: Saraiva, 2009.

BEDAQUE, José Roberto dos Santos. Os elementos objetivos da demanda examinados à luz do contraditório. In: CRUZ E TUCCI, José Rogério; BEDAQUE, José Roberto dos Santos (Coord.). Causa de pedir e pedido no processo civil. São Paulo: RT, 2002.

BUENO, Cassio Scarpinella. A nova etapa da reforma do Código de processo civil. 2. ed. São Paulo: Saraiva, v. 2, 2006.

BRIDA, Nério de Andrade. A (in) constitucionalidade da súmula impeditiva de recursos. Revista de processo. São Paulo, v. 32, n. 151, p. 185-194, 2007.

CÂMARA, Alexandre Freitas. Lições de direito processual civil. 16. ed. Rio de Janeiro: Lumen juris, v.2, 2008.

CAPELLETTI, Mauro; GARTH, Bryant. Acesso à Justiça. Tradução brasileira de Ellen Gracie Northfleet. Porto Alegre: Fabris, 1988. Reimpresso em 2002.

CEI, Marcelo Tuze. Súmula impeditiva de recursos: integração, interpretação, constitucionalidade e efetividade. Revista de processo. São Paulo, v. 34, n. 173, p. 201-231, 2009.

CINTRA, Antônio Carlos de Araújo; GRINOVER, Ada Pellegrini; DINAMARCO, Cândido Rangel. Teoria Geral do Processo. 22. ed. São Paulo: Malheiros, 2006.

CRUZ E TUCCI, José Rogério. Garantia do processo sem dilações indevidas. In: CRUZ E TUCCI, José Rogério (Coord.). Garantias constitucionais do processo civil. São Paulo: RT, 1999.

DINAMARCO, Cândido Rangel. A instrumentalidade do processo. 14. ed. São Paulo: Malheiros, 2008.

DINAMARCO, Cândido Rangel. Instituições de direito processual Civil. 6. ed. São Paulo: Malheiros, v. 1, 2009.

DONOSO, Denis. Súmula impeditiva de recursos. Constitucionalidade, juízo de admissibilidade recursal, cabimento, recorribilidade e outras questões polêmicas sobre o novo art. 518, parágrafo $1^{\circ}$, do CPC. Revista dialética de direito processual. São Paulo, n. 47, p. 32-44, 2007. 
MARINONI, Luiz Guilherme; ARENHART, Sérgio Cruz. Processo de conhecimento. 7. ed. São Paulo: RT, v. 2, 2008.

MARINONI, Luiz Guilherme. Garantia da tempestividade da tutela jurisdicional e duplo grau de jurisdição. In: CRUZ E TUCCI, José Rogério (Coord.). Garantias constitucionais do processo civil. São Paulo: RT, 1999.

MOREIRA, José Carlos Barbosa. Comentários ao Código de Processo Civil. 12. ed. Rio de Janeiro: Forense, v. 5, 2006.

MELLO, Rogério Licastro Torres de. Atuação de ofício em grau recursal. São Paulo: Saraiva, 2010.

MENDES, Gilmar Ferreira; COELHO, Inocêncio Mártires Coelho; BRANCO, Paulo Gustavo Gonet. Curso de direito Constitucional. 2. ed. São Paulo: Saraiva, 2008.

MESQUITA, Gil Ferreira Mesquita. A garantia da razoável duração do processo e seus reflexos para o direito processual civil brasileiro. In: MESQUITA, Gil Ferreira de; ROSSI, Alexandre Luiz Bernardi (Coord.). Maioridade constitucional: estudos em comemoração aos dezoito anos da Constituição federal de 1988. São Paulo: Lemos \& Cruz, 2008.

NERY JUNIOR, Nelson. Princípios do Processo na Constituição Federal. 9.ed. São Paulo: RT, 2009.

Teoria Geral dos Recursos. 6.ed. São Paulo: RT, 2004.

OLIVEIRA, Carlos Alberto Alvaro de. Garantia do contraditório. In: CRUZ E TUCCI, José Rogério (Coord.). Garantias constitucionais do processo civil. São Paulo: RT, 1999.

PARENTE, Eduardo de Albuquerque. A súmula impeditiva de recursos e o sistema de precedentes. In: CARMONA, Carlos Alberto (Coord.). Reflexões sobre a reforma do Código de processo civil. São Paulo: Atlas, 2007.

RODRIGUES, Walter dos Santos. A duração razoável do processo na emenda constitucional $\mathrm{n}^{\circ}$ 45. Revista eletrônica de direito processual. Rio de Janeiro, p. 319-335, 2008.

Disponível: $<\mathrm{http}$ //www.arcos.org.br/periodicos/revista-eletronica-de-

direitoprocessual/volume-ii\#topo >. Acesso em: 10 nov. 2011

ROSAS, Roberto. Direito processual constitucional: princípios constitucionais do processo civil. 3. ed. rev., atual. e ampl. São Paulo: RT, 1999.

SÁ, Djanira Maria Radamés de. A súmula impeditiva de recursos criada pelo art. $518, \S 1^{\circ}$ do CPC. In: MESQUITA, Gil Ferreira de; ROSSI, Alexandre Luiz Bernardi (Coord.).

Maioridade constitucional: estudos em comemoração aos dezoito anos da Constituição federal de 1988. São Paulo: Lemos \& Cruz, 2008.

SILVA, José Afonso da. Curso de direito Constitucional Positivo. 18. ed. rev. e atual. São Paulo: Malheiros, 2000. 
TESHEINER, José Maria Rosa. Nova Sistemática Processual Civil. 2. ed. Caxias do Sul: Plenum, 2006.

WAMBIER, Luiz Rodrigues; WAMBIER, Teresa Arruda Alvim; e MEDINA. Breves

Comentários à $\mathbf{2}^{\mathbf{a}}$ fase da reforma do Código de processo civil. 2. ed. São Paulo: RT, 2002. 